\title{
Supercritical Carbon Dioxide as Non-Thermal Alternative Technology for Safe Handling of Clinical Wastes
}

\author{
A. N. Efaq ${ }^{1} \cdot$ Nik Norulaini Nik Ab. Rahman ${ }^{2}$. \\ H. Nagao $^{3}$ - A. A. Al-Gheethi ${ }^{4}$ - Md Shahadat ${ }^{2}$. \\ M. O. Ab. Kadir ${ }^{1}$
}

Received: 29 January 2015 / Accepted: 12 October 2015 / Published online: 6 November 2015

(C) Springer International Publishing Switzerland 2015

\begin{abstract}
The expansions of communities and cities over the last two decades have led to the increase of the number of health care facilities, and thus, clinical wastes are generated in significant amounts. Clinical wastes are a potential source for many pathogens such as viruses, parasites, fungi and bacteria. Therefore, clinical wastes should be treated before disposal into the environment. The incineration is the most common technology applied for the treatment process. However, the negative effects of incineration on humans and the environment have led scientists to define alternative technologies for the safe disposal of clinical waste. Numerous treatment technologies have been investigated as an alternative for incineration, such as autoclave and microwave. These technologies generally depend on temperature while the recent direction is to use a non-thermal sterilization processes. $\mathrm{SC}-\mathrm{CO}_{2}$ is one of the nonthermal sterilization technologies, which depends on pressure and low temperature. Currently, $\mathrm{SC}-\mathrm{CO}_{2}$ has been extensively used for the inactivation of microorganisms in food and pharmaceutical industries. However, the application of $\mathrm{SC}-\mathrm{CO}_{2}$ in treating clinical wastes has been on a rise. Studies conducted on the inactivation of fungi in food, normal saline and growth media indicate that $\mathrm{SC}-\mathrm{CO}_{2}$ has the ability to inactivate these organisms. In clinical wastes, $\mathrm{SC}-\mathrm{CO}_{2}$ has been found to be effective in the inactivation of pathogenic bacteria. Therefore, this review paper focuses on the potential of using $\mathrm{SC}-\mathrm{CO}_{2}$ as alternative technology for inactivating fungi in clinical wastes.
\end{abstract}

A. N. Efaq

eanm1984@gmail.com

$\triangle$ Nik Norulaini Nik Ab. Rahman norulain@usm.my

1 School of Industrial Technology, University Science Malaysia, 11800 Penang, Malaysia

2 School of Distance Education, University Science Malaysia, 11800 Penang, Malaysia

3 School of Biological Science, University Science Malaysia, 11800 Penang, Malaysia

4 Faculty of Civil and Environmental Engineering, University Tun Hussein Onn Malaysia, Johor, Malaysia 
Keywords $\mathrm{Clinical}$ wastes $\cdot \mathrm{Fungi} \cdot \mathrm{SC}-\mathrm{CO}_{2} \cdot \mathrm{High}$ pressure $\cdot$ Inactivation mechanism

\section{Introduction}

Clinical wastes contain several pathogens such as viruses, parasites, fungi and bacteria (Saini et al. 2004; Park et al. 2009). However, fungi present more importance than bacteria, since they could grow and multiply in clinical wastes without any intermediates as hosts and have quite simple nutritional requirements. These characteristics are common in some bacteria. Moreover, fungi can grow at low levels of water activity compared to bacteria $\left(a_{w} 0.60-0.85\right.$ vs 0.89- 0.97, respectively) and have the ability to produce thousands of external spores which can easily distribute to the environment, while bacteria produce endospores (Jay 2000; Deacon 2005). Besides, the nature and the environmental factors such as temperature, nutrients, moisture, $\mathrm{pH}$ is favourable for their growth in clinical wastes (U.S. EPA 1990). Thus, clinical wastes have become one of the main sources for human infection, and therefore, they should be treated before final disposal. The incineration of clinical waste is effective for elimination of pathogenic microorganisms. However, one of the main disadvantages of incineration is the secondary production of toxic gases, which might cause detrimental effects on humans and the environment. Alternative technologies, such as chemical disinfection and irradiation, are unable to completely damage the pathogens. Thus, the treated clinical wastes still contain infectious agents due to weaknesses and disadvantages of these techniques (Tsakona et al. 2007; Nemathaga et al. 2008). Furthermore, these technologies create health hazard and environmental pollution rather than reducing infectious risk in the waste. $\mathrm{SC}-\mathrm{CO}_{2}$ is a nonthermal sterilization technique, which depends on the solubility and diffusion of pressure through the cell membrane of microorganism (Zhang et al. 2006a). It is non-toxic, inflammable and environmentally friendly (Spilimbergo et al. 2002; Zhang et al. 2006b). Recent studies have demonstrated that $\mathrm{SC}-\mathrm{CO}_{2}$ is effective for the inactivation of microorganisms and enzymes in different materials such as culture media, liquid foods, fresh cut fruits, vegetables and meats (Spilimbergo et al. 2010; Bi et al. 2011; Ferrentino et al. 2012; Ramirez-Rogrigues et al. 2013). The inactivation of fungi in food has been demonstrated to be due to its antimicrobial effects, especially at high pressures (Zhang et al. 2008; Kim et al. 2009; Chung et al. 2013; Ferrentino et al. 2013). Studies conducted on inactivation of pathogenic bacteria in clinical wastes have revealed that $\mathrm{SC}-\mathrm{CO}_{2}$ is an effective technique for the reduction of pathogenic bacteria; clinical wastes treated by $\mathrm{SC}-\mathrm{CO}_{2}$ have met the standard limits recommended by STAATT (2005) for safe disposal (Banana 2013; Hossain 2013). Therefore, $\mathrm{SC}-\mathrm{CO}_{2}$ could be used as an alternative technology for clinical waste treatment. In the present review, the potential of $\mathrm{SC}-\mathrm{CO}_{2}$ for inactivation of fungi in clinical wastes is viewed which depends upon the inactivation mechanism of $\mathrm{SC}-\mathrm{CO}_{2}$ against fungi in food, normal saline and growth media that has been described by various authors in the last years.

\section{Clinical Wastes}

Clinical wastes are generally health wastes that are hazardous and represent a potential source of human infection. EPA (2009) identified clinical wastes as any wastes contaminated with blood or human body fluids and generated from healthcare facilities during the treatment of patients or during research projects. WHO (2005) indicated that these wastes include; sharps 
(needles, scalpels, etc.), laboratory cultures, blood and body fluid products, pathological wastes and specimens collected from patients. Healthcare facilities include medical, dental, nursing, diagnostic laboratory, podiatry, pharmaceutical, tattooing, emergency, body piercing, services and blood banks, among others. The various types of clinical wastes are presented in Fig. 1.

The amount of clinical wastes generated from healthcare facilities have been increased during the recent years. Clinical wastes represent $12.5-69.3 \%$ of the total healthcare wastes; among them, 10-25\% are high-risk wastes (WHO 2005; Visvanathan 2006; Nemathaga et al. 2008; Shinee et al. 2008; Efaq and Al-Gheethi 2015). WHO (2000) has estimated the quantities of clinical wastes generated from healthcare facilities to be between 0.5 and $3 \mathrm{~kg} /$ bed/day. In Malaysia, the average of healthcare waste generation is $1.9 \mathrm{~kg} / \mathrm{bed} / \mathrm{day}$. This value is less than those reported in North and South America and Western Europe, but higher than that estimated in Pakistan, Thailand, India and China (Fig. 2). The variance found among these countries are a result of different level of economic strength and healthcare facilities, size and type of the medical institution, and number of patient care (Marinkovic et al. 2008; Nemathaga et al. 2008). As presented in Fig. 2, it can be noted that the rate of clinical wastes generated

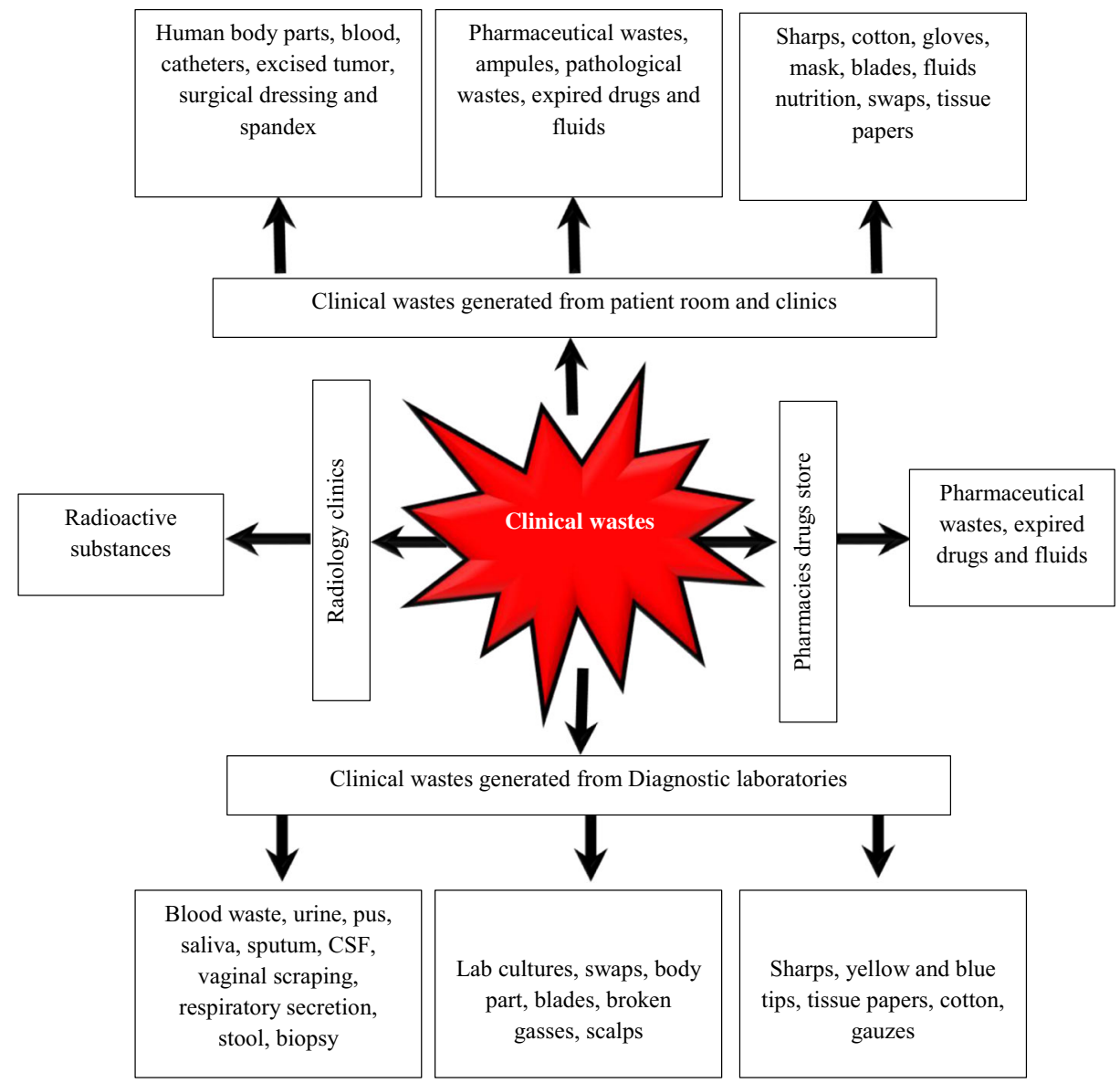

Fig. 1 Clinical wastes generated from the healthcare facilities 


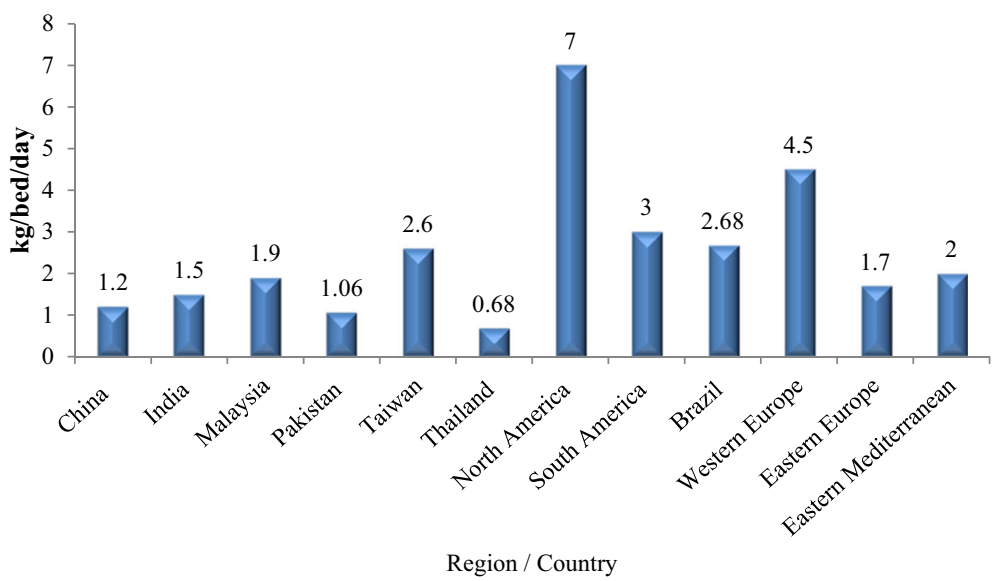

Fig. 2 Estimated average healthcare waste generation in different region in the world (WHO 2005; Visvanathan 2006; Johannessen 1997; Da Silva et al. 2005; Cheng et al. 2009; Ruoyan et al. 2010).

from healthcare establishments depends on the level of development of the country. Developed countries generate clinical wastes at a higher rate than that of developing countries (Pruss et al. 1999; Marinkovic et al. 2008; Nemathaga et al. 2008). According to Halbwachs (1994), the health-care wastes generated from high-income countries ranged between 1.1 and $12.0 \mathrm{~kg} /$ person, while low-income countries produce between 0.5 and $3.0 \mathrm{~kg} /$ person.

The growing interest in controlling and monitoring clinical wastes aims to determine a safe and effective management of these wastes, in order to protect humans and the environment from pathogenic microorganisms associated with these wastes (WHO 2005; Alagoz and Kocasoy 2008; Marinkovic et al. 2008; Park et al. 2009). Several countries have adopted the regulations for the proper management of clinical wastes. In the UK, the Department of Health (2013) has published the guidelines for the management of healthcare waste. In the USA, EPA (2009) has regulated the organization of clinical wastes, including the storage, transport, treatment and disposal processes. In Brazil, three laws include regulations related to best practices for handling clinical waste, i.e., the law of environment No. 7 (1982), law of the atmospheric and air protection (1992), and law of transport of hazardous materials (2005). In Australia, the legislation for collection, segregation and treatment of clinical waste has been in practice since the 1990s by the Ministry of Health (1998). In Turkey, the Ministry of Environment and Forestry, controls the management of healthcare wastes since 1993; the legislation includes the procedures for segregation, collection, transportation, storage of clinical wastes and the transportation to the final disposal area (Ministry of Environment and Forestry 2005).

In Malaysia, the regulations for clinical wastes management have started in 1989 (Razali and Ishak 2010; Ambali et al. 2013). These regulations are described in more detail in a new version of Environmental Quality (Scheduled Wastes) Regulations (2005). Three concession companies have been appointed by the government to handle and treat clinical wastes generated in public hospitals in Malaysia (Chuah et al. 2009), which use incineration for the final treatment of the clinical wastes; however, with increasing quantities of wastes, the needs for more incinerators to treat clinical wastes has also increased. In contrast, among the 150 incinerators constructed in New York State, USA, in 1990, 142 have been closed by 2000 due to the negative impacts on human health and the environment. 
Consequently, it is imperative that alternative technologies for treatment of clinical wastes, especially non-thermal sterilization technologies, be sought. In the last years, alternative technologies for treatment of clinical wastes have been ventured; for instance, thermal treatment (microwaving, macrowaving, moist and dry heat, laser, infrared, plasma, gasification and pyrolysis), chemical disinfection (chlorination, ozonation, hydrogen peroxide and sodium hydroxide) and irradiation treatment (UV, Cobalt 60, electron beam) (STAATT 2005). In Malaysia, these technologies have not been applied at a large scale yet, and autoclaves are used in numerous hospitals as a primary treatment, while incineration is used as final treatment. Few studies have been conducted on the treatment of clinical wastes by autoclave, microwave and supercritical carbon dioxide at laboratory scale, which show the potential in applying these techniques at full scale (Banana 2013; Hossain 2013). However, these studies focused only on pathogenic bacteria, whereas clinical wastes contain several other pathogenic organisms including fungi and viruses. Therefore, more studies are necessary to accurate evaluate these techniques before full-scale application. In the United States, currently steam autoclave is used for treatment of clinical wastes, whereby there are more than 100 commercial autoclave plants for processing infectious waste (Hossain 2013).

\section{Health Risks of Clinical Waste}

Information regarding the microorganism presence in wastes generated by healthcare facilities can shed light on the level of serious potential of harm to the public and the environment (Sherman 2007). This is certainly critical and regulations imposed by countries consider this matter. The abatement of the risks has often been placed within the management as in the effective waste segregation or minimization of clinical waste that may reduce the biohazards risk of these wastes. The risks that are associated with the presence of microorganisms must, however, focus on the inactivation of these pathogens as soon as the wastes are generated. Effective clinical waste segregation or minimization may reduce the biohazards risk of these wastes, however, the infectious agents to healthcare worker are still possible because of the infectious nature for these wastes. The health risk of clinical wastes that needs to be assessed is the presence of pathogenic microorganisms. As Park et al. (2009) aptly pointed out, infectious threat to healthcare worker is still possible because of the presence of the infectious pathogens in these wastes. They identified various types of pathogens, bacteria and fungi that are most commonly considered as health risks due to the ability of these organisms to multiply and persist for a long time in clinical wastes, while viruses cannot survive in clinical wastes without a host organism. The argument is congruent to Hall (1989) and Saini et al. (2004), who stressed that the environmental factors of clinical wastes such as presence of carbon and nitrogen source (sugars, protein, starch, fats and other compounds), and growth factors are suitable for growth and survival of bacteria and fungi. In the next section, the presence of bacteria and fungi in the clinical waste is reviewed.

\subsection{Pathogenic Bacteria in Clinical Wastes}

Clinical wastes contain a wide range of pathogenic bacteria; the types of these pathogens depend on the source and composition of clinical wastes. Pathogenic bacteria in the diagnostic specimens, lab cultures and others healthcare facilities are suspected to be associated with the contamination in clinical wastes. Bacillus spp., Staphylococcus spp., Streptococcus spp., 
Klebsiella, Enterobacter spp., Escherichia coli, Salmonella spp., and Pseudomonas aeruginosa have been detected as most common in clinical wastes (Luksamijarulkul et al. 2006; Crawford and Daum 2008; Eckmanns et al. 2008; Oyeleke and Istifanus 2009; AlGhamdi 2011; Anitha and Jayraa 2012).

Saini et al. (2004) stated that pathogenic bacteria have the potential to grow and multiply in clinical wastes after $24 \mathrm{~h}$ of storage period to reach the infective dose, and suggested that the clinical waste should be treated within $24 \mathrm{~h}$ of generation. Alagoz and Kocasoy (2008) have recovered total coliform bacteria, E. coli, Enterobacter sp., Pseudomonas spp., S. aureus, B. cereus, Salmonella spp. and Legionella sp. from clinical wastes in Istanbul, Turkey. Park et al. (2009) determined the presence of Staphylococcus spp., Lactobacillus spp., Pseudomonas spp., Micrococcus spp., Brevibacillus spp., Kocuria spp., Propionibacterium acnes, Microbacterium oxydans, Corynebacterium diphtheria and E. coli in clinical wastes collected from five major hospitals in South Korea.

Hossain (2013) has isolated Acinetobacter lwaffii, A. baumannii, E. coli, E. faecalis, $K$. pneumonia, Proteus mirabilis, Serratia marcescens, S. liquefaciens, Salmonella spp., $S$. aureus, $P$. aeruginosa, $S$. epidermidis, $S$. pyogens, $S$. agalactiae from the clinical solid wastes collected from different sections of Hospital Lim Wah Ee (Dental section, microbiological laboratories, dermatology, obstetrical and gynaecology units) in Malaysia. The study illustrated that clinical solid wastes collected from microbiology laboratories and dental section contained the highest number of pathogenic bacteria. Banana (2013) examined the presence of pathogenic bacteria in blood waste, urine waste, swaps, pus and tissue wastes collected from general hospital of Penang, Malaysia. E. coli, E. faecalis, K. pneumonia, P. mirabilis, P. aeruginosa, $S$. aureus, $S$. pyogens and Salmonella spp. were the most common.

The presence of pathogenic bacteria in clinical wastes represent real hazards for human due to ability of these pathogens to cause severe diseases and resistance of antibiotics after the disposal into the environment. A wide range of antibiotic resistant bacteria has been isolated in the environment (Al-Gheethi and NorliI I 2014; Al-Gheethi et al. 2014) isolated E. coli, Salmonella spp. and E. faecalis from sewage effluents. These bacteria have exhibited multiresistance for many antibiotics such as ciprofloxacin, ampicillin, cephalexin and amoxicillin. Salmonella spp. are the most relevant pathogens they can cause diseases to all organisms from insects to mammals (Bohm 2004). Enteric fever is a collective term given to the invasive infections caused by $S$. typhi, the cause of typhoid fever, and by the strains of $S$. paratyphi that cause paratyphoid fever (Bumann et al. 2000). A large proportion of $S$. typhimurium isolates are resistant to multiple antimicrobial drugs; $39 \%$ were resistant to one or more drugs and $23 \%$ had a five-drug resistance pattern characteristic (CDC 2006). E. coli is harmless, but some serotypes are pathogenic; among them, enterohaemorrhagic strain E. coli O157:H7, which can cause gastrointestinal disorders such as: bloody diarrhoea, cramping and abdominal pain and the infectious "hemolytic uremic syndrome," and has been increasingly involved in food poisoning outbreaks (Buzrul 2009; Fijalkowski et al. 2014). E. coli is accountable for neonatal meningitis and pneumonia infection (Dobrindt and Hacker 2008).

P. mirabilis is the second most common in urinary tract infection patients; this bacterium is an opportunistic pathogens that causes secondary infection of hospital-acquired illnesses, including wound infection and septicemia (Coker et al. 2000; Fluit et al. 2000). P. mirabilis has the ability to survive for long time in different environments of healthcare facilities and hospitals (Pagani et al. 2002). K. pneumonia is the main causative of bronchopneumonia and bronchitis (CDC 2009). $K$. pneumonia has multi-resistance patterns of $\beta$-lactam antibiotics due to ability to produce extended-spectrum $\beta$-lactamases (Podschun and Ullmann 1998; Renois et al. 2011). 
P. aeruginosa has a potential pathogenicity for human and represents one of the major causes of nosocomial infections, as well as it is a common cause for secondary infection of patients in the last stages of autoimmune diseases or AIDS (Kiil et al. 2008). E. faecalis has also been reported as major nosocomial pathogen (Facklam and Washington 1991). E. faecalis strains have the ability to resist numerous antibiotics such as $\beta$-lactam and aminoglycosides (Garrison et al. 2005). Thus, this bacterium is an important pathogen in hospital infection (Facklam and Washington 1991; Freitas et al. 2011). Staphylococcus spp. are bacteria that commonly colonise human skin and mucosa (e.g., inside the nose). It can also cause disease, particularly if there is an opportunity for the bacteria to enter the human body such as in the case of burns. Among the S. aureus strains, Methicillin-resistant Staphylococcus aureus (MRSA) is the greatly feared strains due to the ability to resist most antibiotics in medical care (Vickery 1993). Al-Gheethi et al. (2015) have found that S. aureus recovered from environment exhibited multi-resistance for ampicillin, amoxicillin, ciprofloxacin, tetracycline and erythromycin. It can be concluded that the high diversity of pathogenic bacteria in clinical wastes confirm the need to eliminate the health risk for the wastes by choosing the more efficient treatment processes, and thus, prevent the arrival of pathogens into the environment and the humans.

\subsection{Fungi in Clinical Wastes}

Many fungi can be found in hospitals and other clinical facilities or laboratories, which form a composite in the wastes, generated from these premises. The importance of fungi as infectious agents is well recognized worldwide. Fungi cause several serious diseases on human; of particular concern is the opportunistic pathogens, including C. neoformans, Candida spp., Aspergillus spp., Mucorales, Fusarium spp., Paecilomyces spp., Alternaria spp. and Scedosporium spp. which is also called invasive fungal infections (IFIs) (Beck-Sague and Jarvis 1993; Sifuentes-Osornio et al. 2012; Tamring et al. 2014). The prevalence of IFIs has increased since the 1990s due to an intensive immunosuppressive chemotherapy, increasing of immune-compromised patients and the widespread use of broad-spectrum antibiotics (van Burik and Magee 2001).

Aspergillus spp. are ubiquitous fungi and natural inhabitants of soil, water and organic vegetation and debris (Ryan 2004). The spores of Aspergillus spp. have the ability to survive for a long time in the environment and they have been isolated from dust produced during the course of hospital renovation (Araujo et al. 2006). Aspergillus can cause many diseases for human. A. fumigatus, A. flavus, A. terreus, A. niger and A. nidulans are the most common species (Hogan et al. 1996; Macêdo et al. 2009; Şahil and Otag 2013). Invasive aspergillosis (IA) is the second most common cause of nosocomial fungal infections (Segal 2009). It has detected in $57.6 \%$ of immune-compromised patients (Pagano et al. 2011).

Penicillium spp. are the most common fungi in the environment; they have low pathogenicity for humans. However, in immune-compromised patients they can be virulent pathogens and can cause death (Oshikata et al. 2013). Penicilliosis marneffei has been recorded as the third most common opportunistic infection among patients infected with human immunodeficiency virus in certain parts of Southeast Asia, India, and China (Duong 1996; Vanittanakom et al. 2006). Barcus et al. (2005) reported an intestinal invasion and disseminated disease associated with Penicillium chrysogenumin in the USA. $P$. digitatumhas was detected as infectious agent for human and caused a fatal pneumonia infection in Brazil (Oshikata et al. 2013). 
Few studies have been published on the presence of fungi in clinical wastes, but these studies have revealed a wide range of fungi. Neely and Orloff (2001) investigated the survival of Aspergillus spp., Fusarium sp., a Mucor sp., and Paecilomyces sp. on hospital fabrics and plastics, such as cotton, terry, blend, polyester, spandex, polyethylene and polyurethane in the USA. A. flavus, A. niger, A. fumigatus and A. terreus can survive for more than 30 days on cotton, blend, polyster, polyethylene and polyurethane. Fusarium sp. can survive for 10 days on cotton, blend, spandex and polyester, and for more than 30 days on polyethylene. Mucar sp. persisted more than 20 days on all types of hospital fabrics and plastics except of terry (16 days). The maximum survival of Paecilomyces sp. was noted on spandex and polyurethane (11 days). Fungi also have the ability to live in clinical wastes disposed into landfills. Oyeleke and Istifanus (2009) have studied the presence of fungi in 24-hour hospital waste samples taken from different hospital waste dumpsites and their surrounding soils in Nigeria. The fungi isolated included: A. niger (34.48 vs. $44.44 \%$ ), A. flavus (13.79 vs. $3.70 \%$ ), A. parasiticus (0 vs. $7.41 \%$ ), A. visicolor (3.45 vs. $3.45 \%$ ), A. nidulans (0 vs.11.11\%), P. rubrum (6.86 vs. $3.70 \%$ ), T. roseum (0 vs. $3.70 \%$ ), P. viricadum (6.90 vs. $0 \%$ ), $R$. nigricans (27.59 vs. $18.52 \%$ ) and Microsporumcanis (6.9 vs. $0 \%$ ).

The reproduction of fungi by sexual spores lead to distribute these spores in air, therefore, even if the clinical wastes generated from different sections of healthcare facilities are free from fungi. These wastes may be exposed to contamination during the storage period that precedes the final treatment. Vieira et al. (2010) evaluated airborne fungi in the Brazilian dental healthcare environment and in the waste storage room. A total of 104 fungal isolates were recovered, $69 \%$ from the waste storage room and $31 \%$ from the clinical/surgical environment. The fungal isolates have been identified as Cladosporium spp. (60.5\%), Mycelia sterilia (10.5 \%), Penicillium spp. (6.7 \%), Rhodotorula sp. (3.8 \%), A. niger (2.8 \%), Fusarium sp., F. solani, Torula sp., Charalopsis sp., Curvularia sp. (1.9\% each), Cunninghannella sp., Basipetospora sp., Scopulariopsis sp., Aureobasidium sp., Scytalidium sp. and Alternaria sp. ( $0.06 \%$ each). Cladosporium spp. occurred in $43.7 \%$ of samples recovered from the clinic surgical environment and $68 \%$ from the waste storage room.

Pathak (2012) investigated occurrences of airborne fungi in upwind and downwind direction of Dental College hospital extramural environment in India. About 270 and 294 fungi have been isolated from 24 samples that were collected from the upwind and downwind directions, respectively. Aspergillus spp. (32 vs. $34 \%$ ), Alternaria spp. (11\% vs. $7 \%$ ) and Penicillium spp. ( $9 \%$ vs. $7 \%$ ) were predominantly present in Dental College hospital extramural environment at upwind and downwind directions, respectively. Other fungi have also been isolated in this study, including Mucor sp., Rhizopus sp. Cladosporium sp., Curvularia sp., Epicoccum sp., Fusarium sp., Geotrichum sp., Trichothecium sp. and Trichoderma sp.

Efaq et al. (2015) studied the fungal diversity in clinical wastes generated from healthcare facility in Penang Malaysia. Fungi were detected in $83.7 \%$ of the samples. Aspergillus section Nigri, A. niger, A. fumigatus, A. tubingensis, $P$. simplicissium, $P$. waksmanii and C. lunata were the most predominant ones. Among 36 fungal species, 26 species were grown at $37{ }^{\circ} \mathrm{C}$, indicating the ability of these opportunistic fungal species to infect the human.

According to the above literature, the fungi represent an important source of contamination in clinical wastes due to the presence of necessary nutrients for fungal growth in these wastes, as well as the ability of fungal spores to survive in the environment. Şahil and Otag (2013) studied the survival of Aspergillus, Fusarium spp., Acremonium spp., Alternaria spp. and Cladosporium spp. isolated from clinical samples in sand stored inside vials at room 
temperature for 1, 2, 3, 6 and 12 months. They illustrated that Fusarium spp. have persisted for 6 months, while Aspergillus spp., Acremonium spp., Alternaria spp. and Cladosporium spp. have subsisted for 12 months.

\section{$4 \mathrm{SC}-\mathrm{CO}_{2}$ as an Alternative Technology for Treatment of Clinical Wastes}

The risks associated with clinical wastes due to high diversity of pathogens in these wastes have been well documented in literature (Pruss et al. 1999; Alagoz and Kocasoy 2008; Park et al. 2009). The clinical wastes have less load of pathogenic microorganism compared with the domestic refuse. This is due to the organic contents in these wastes which is less than $40 \%$ compared to that in the total solid. However, the clinical wastes are responsible for more than $60 \%$ of the costs of the treatment processes. It has been suggested that in order to minimize the amount of clinical wastes with inherent infectious risk, clinical waste management should incorporate waste minimization and additional segregation of wastes at source. Such initiatives can vastly reduce the volumes of clinical wastes sent for disposal; significant cost savings may accrue. Nonetheless, this does not circumvent the infectious nature and the risks borne by clinical wastes. In order to handle the infectious nature inherent in these pathogen contaminated wastes, proper inactivation treatment is deemed to be of great urgency (Blenkharn 2005). Many treatment technologies have been extensively investigated to inactivate and remove these infectious pathogenics from clinical wastes for safe disposal into the environment (Phillips 1999; WHO 2005; Brog 2007). The developments of these technologies depend on understanding the factors affecting microorganism requirements. Many factors affect microorganism survival and growth in the environment. Some of these factors include $\mathrm{pH}$, water activity, moisture content, nutrients and disinfectants, while others are physical factors such as temperature, pressure and irradiation (Johnson et al. 2005; Hungaro et al. 2014).

Temperature is one of the more critical factors affecting microorganism survival (Tang 2009). This feature made temperature a basic parameter for several sterilization technologies, for instance incineration, microwaves, ovens and autoclaves. Temperature has been used as a single factor for microorganism inactivation as in the case of incineration and dry sterilization (oven). In the incineration, the temperature may be ranging between 900 and $1200{ }^{\circ} \mathrm{C}$, which kills microorganisms rapidly (Niwagaba 2009; Razali and Ishak 2010). In some sterilization technologies, the temperature is combined with other factors to enhance the inactivation rate. For example, the sterilization processes by oven relies on temperature and time. Temperature between 160 and $180{ }^{\circ} \mathrm{C}$ for $2 \mathrm{~h}$ are sufficient to kill living microorganisms. The moist temperature, pressure and time are the main factors for the inactivation of microorganisms by the autoclave (Agalloco et al. 1998). The sterilization process conducted at $121{ }^{\circ} \mathrm{C}$ under pressure 15 psi for 15 min destroys the microorganisms by the irreversible denaturation of enzymes and structural proteins (Lee et al. 2004). In microwaves, the inactivation of microorganism are due to temperature associated with electromagnetic radiation (Watanabe et al. 2000).

Regarding microbial inactivation, STAATT (2005) reported that treatment technology for clinical wastes should have the ability to inactive the biological indicators by 6 log reductions with initial concentration $10^{6}$ cells $/ \mathrm{mL}$ (Tables 1 and 2). The incinerator is the most effective to achieve these standards. Evidence has shown that incineration temperatures as low as $300{ }^{\circ} \mathrm{C}$ for $15 \mathrm{~min}$ or very high at $1100{ }^{\circ} \mathrm{C}$ for $3 \mathrm{~min}$ were adequate to sterilize test pieces which could achieve a promising sterilization assurance level of $10^{6}$ reduction (Blenkharn 2005). Autoclave 
Table 1 Biological indicators recommended by STAATT (2005) for the testing of microbial inactivation efficacy in medical wastes by alternative technologies

\begin{tabular}{ll}
\hline Group & Indicator microorganism \\
\hline Vegetative Bacteria & $\begin{array}{l}\text { Staphylococcus aureus (ATCC 6538) } \\
\text { Pseudomonas aeruginosa (ATCC 15442) } \\
\text { Candida albicans (ATCC 18804) } \\
\text { Fungi }\end{array}$ \\
& Penicillium chrysogenum (ATCC 24791) \\
& Polio 2 or Polio 3 \\
Viruses & MS-2 Bacteriophage (ATCC 15597-B1) \\
& Mycobacterium terrae \\
Mycobacteria & Mycobacterium phlei \\
& Mycobacterium bovis (BCG) (ATCC 35743) \\
& Bacillus stearothermophilus (ATCC 7953) \\
Bacillus subtilis (ATCC 19659)
\end{tabular}

and microwave also have the ability to achieve the log reductions required for the microorganisms and have achieved $6 \operatorname{logs}(99.9999 \%)$. The incinerators, autoclaves and microwaves techniques have been studied extensively for inactivation of pathogens in the clinical wastes by many authors (Da Silva et al. 2005; Shinee et al. 2008; Bendjoudi et al. 2009; Abd El-Salam 2010; Banana 2013).

Furthermore, it has been documented previously that pathogens require a certain temperature for growth that covers a range in between 10 and $40{ }^{\circ} \mathrm{C}$, with optimum temperature of pathogenic bacteria being $37{ }^{\circ} \mathrm{C}$, while fungi grow well at $28{ }^{\circ} \mathrm{C}$ (Raghubeer and Matches 1990; Smerage and Teixeira 1993; Russell 1999). The fungal spores are destructed at $70-80{ }^{\circ} \mathrm{C}$ for $10 \mathrm{~min}$ (Aneja 2001). Therefore, if the waste temperature increases during the treatment process above the "optimum temperature", the risk associated with the pathogenic microorganism becomes zero. The denaturation and inactivation of metabolic enzymes of the microorganisms are enough to kill the microorganism cells (Smerage and Teixeira 1993; Russell 1999). Hence, it is apparent that there is no necessity to use the incineration, microwave or even autoclave to inactivate these organisms. Indeed, the physiochemical characteristics of clinical wastes play an important role in the treatment process. Steam autoclave has been used for medical instruments in hospitals. It has been used for the treatment of cultures in the laboratories for many years. One of the main differences between medical instruments and medical waste is in the concentrations of pathogens. In the clinical waste, high contents of microorganisms are available along with a more complex matrix. Besides that, many factors affect the efficiency of steam autoclave treatment of clinical wastes. The size of the waste load, composition of waste, steam penetration of the waste, package of the waste for treatment, and

Table 2 Reduction level regulated by STAATT (2005)

\begin{tabular}{ll}
\hline Level & Requirement \\
\hline Level I & $6 \log _{10}$ inactivation of vegetative bacteria, fungi, and lipophilic viruses \\
Level II & $6 \log _{10}$ inactivation of mycobacteria \\
Level III & $4 \log _{10}$ inactivation of $B$. stearothermophilus or B. subtilis spores \\
Level IV & $6 \log _{10}$ inactivation of $B$. stearothermophilus spores \\
\hline
\end{tabular}


orientation of the waste load within the autoclave affect significantly the inactivation. Density of the clinical waste items may prevent adequate treatment. Radioactive hazardous and cytotoxic wastes are also inappropriate for the treatment by steam autoclave (U.S. EPA 1990). Hence, the authors suggested secondary treatment of the autoclaving wastes before final disposal (Jang et al. 2006; Al-Khatib and Sato 2009). Salkin (2003) revealed that microwave treatment was not suitable for all types of clinical waste, with some microorganisms not inactivated by this technique (Cha and Carlisle 2001).

Regarding microbial regrowth among the inactivated microorganisms in clinical waste, post-treatment, moisture is the main factor for occurrence of the regrowth. Therefore, high efficiency of incineration is due to the fact that the dry temperatures reduce the moisture content in the clinical wastes and destruct it to become ash. Thus, the wastes become unsuitable for microorganism growth. In the autoclave, the moist temperature destroys microorganisms but this leads to the increase of moisture contents of the clinical waste. The autoclaved clinical wastes remain recognizable for microbial growth. For this reason, those wastes are suitable for growth of microorganisms from the air or the soil. The regrowth of inactivated microorganisms in clinical wastes treated by autoclave and microwave has been reported previously (Banana et al. 2013).

The selection of the appropriate technology for the treatment of the clinical waste should consider the adverse effects on the environment, and not only the ability to inactivate the pathogens. Besides that, the treatment technology should be easily implementable, ecofriendly, with no toxic by-products and no chemical additives (WHO 2005). Two new concepts have been raised in the few last decades, the Climate Change (Global Warming) and Zero Discharge. Global Warming is defined as the increase of the earth temperature due to emissions of gases $\left(\mathrm{CO}_{2}\right.$ and $\left.\mathrm{CH}_{4}\right)$ into the atmosphere. Stocker et al. (2013) indicated that in 2100 the global surface temperature would increase in the range 1 to $3.4{ }^{\circ} \mathrm{C}$. In Malaysia, the climate temperature has increased at least $1{ }^{\circ} \mathrm{C}$ during the period 1992 to 2013 (DS 2013). It was due to the increase of the industrial activities. Zero discharge is defined as recycling or reuse of wastes, a term raised in 1980 for industrial wastewater.

According to these concepts, and regardless of the inactivation of microorganisms, the treatment technologies that depend on temperature are not the appropriate method for treatment of clinical wastes. High temperature used during incineration would destruct all organic matter in clinical wastes and convert it to ash. Thus, the amounts of discharged clinical wastes to the environment are low. Moreover, the toxic by-product which includes carbon monoxide, nitrogen dioxide, hydrogen chloride, sulphur dioxide, chlorinated hydrocarbons, polycyclic aromatic hydrocarbons, dioxin and furan released from incineration into the atmosphere are more dangerous for human health and also contribute to the increase of the earth temperature (Michelle et al. 2001; Blenkharn 2005; Coker et al. 2009; Ruoyan et al. 2010). Hence, the climate change concept limits the use of incineration.

The use of temperature for autoclave and microwave is lower than incineration, however, both techniques could not destroy the total organic matter. Hence, high amount of wastes are disposed into the environment (Jang et al. 2006). Therefore, in terms of destruction of organic matter and zero discharge both techniques might not be the alternative technologies to incineration.

The concepts of global warming and zero discharge have added strong criteria for selecting the treatment technology of clinical wastes. Therefore, the strategy is to find a non-thermal sterilization technology has the ability to inactivate pathogens and produce recyclable or reusable wastes. As was reviewed above, the temperature is one of the physical factors that 
affect microorganisms. Disinfectants are bactericidal and fungicidal; however, chemical treatment is not the appropriate technology for inactivation of microorganisms due to occurrence of microbial resistance against chemical disinfection and increase of resistance to several antibiotics as well as the negative effect to humans and the environment (Bond 1993).

Pressure is the second physical factor, which is effective on the survival of microorganisms in the environment. In microbial inactivation, the effect of pressure on the inactivation of bacteria has been reported since 1914. Hite et al. (1914) studied the effect of pressure on B. diphthcriae (Corynebacterium diphthcriae) and B. typhosusin in milk; the sample was subjected to $689.475 \mathrm{MPa}$, for an hour daily for 7 days at room temperature. They found that milk enzymes were still active while bacterial cells were completely inactivated. The results obtained in this study have indicated that the pressure was effective for inactivation of bacteria. However, the technique, which was dependent on pressure, was not applied for sterilization of milk. It was due to the fact that the sterilization process takes long time compared to pasteurization.

Larson et al. (1918) investigated the effect of high pressure on bacteria in the liquid using different gases $\left(\mathrm{N}_{2}, \mathrm{CO}_{2}\right.$ and $\left.\mathrm{O}_{2}\right)$. The study concluded that $\mathrm{CO}_{2}$ under $5 \mathrm{MPa}$ destroyed most of the bacterial species (Staphylococcus spp., Streptococcus spp., Bacillus spp.) after $150 \mathrm{~min}$. They explained the mechanism of the pressure due to the acidity of solution when reacting $\mathrm{CO}_{2}$ and $\mathrm{H}_{2} \mathrm{O}$. The high molecular concentration and sudden change of osmotic tension of the liquid were the main factors of this mechanism. The pressure destroyed the bacteria cell wall as tested based on the ability of bacteria to react with gram stain. They noted that cell wall of gram positive bacteria lost the ability to react with crystal violate and the cell appeared as gram negative. According to this study, the pressure of $\mathrm{CO}_{2}$ has more efficiency for inactivation of bacteria during short time (90-150 min) and at low pressure (5 MPa) compared to $\mathrm{N}_{2}$ and $\mathrm{O}_{2}$.

Caldwell (1965) reported that fungi and bacteria exposed to $\mathrm{O}_{2}$ at $1 \mathrm{MPa}$ for $10 \mathrm{~min}$ were completely inactivated. However, the fungal regrowth occurred again, the growth was slow but after few days of treatment process, the normal growth was obtained. It was due to the exposure period that was not too long. Robb (1966) stated similar results; the study investigated the inactivation of 103 fungal species at $1 \mathrm{MPa}$ of oxygen at $25^{\circ} \mathrm{C}$ for 7 days. Among these fungi, 52 species were grown again after treatment, 22 of them regrown even after the treatment process conducted for 14 days. The inactivated fungi during the first few days showed less growth rate than the untreated ones. After that, the growth rate of inactivated and untreated fungi was not different.

Hayakawa et al. (1998) confirmed the effect of pressure as a single factor on the survival of microorganisms. The study investigated the effect of different pressures at low temperatures $\left(60 \mathrm{MPa}\right.$ at $-5{ }^{\circ} \mathrm{C}, 103 \mathrm{MPa}$ at $-10{ }^{\circ} \mathrm{C}$ and $140 \mathrm{MPa}$ at $-15,-20$ and $-22{ }^{\circ} \mathrm{C}$ ) on the inactivation of bacteria, yeasts and fungi. S. cerevisiae, Z. rouxii, L. brevis, E. coli, A. niger and A. oryzae were completely inactivated at $140 \mathrm{MPa}$ when stored in sealed vessels at $-20^{\circ} \mathrm{C}$ for 24 h. Malinowska-Pańczyk et al. (2008) studied the effect of high pressure (60-193 MPa) on Gram-positive and Gram-negative bacteria at zero and sub-zero temperature (zero to $-20{ }^{\circ} \mathrm{C}$ ), for $10 \mathrm{~min}, B$. subtilis and B. cereus were reduced by more than 7 logs at these conditions.

It can be concluded that the main reasons influencing sterilization processes by using pressure was the pressure itself (high pressure was required) and the type of gas $\left(\mathrm{CO}_{2}, \mathrm{~N}_{2}\right.$, $\mathrm{N}_{2} \mathrm{O}$ ). The treatment time and regrowth of inactivated microorganisms depend on these parameters, in addition to the type of organism and time. In order to increase the efficiency of the sterilization process by using pressure, the investigators studied the combination of pressure, temperature and gas type $\left(\mathrm{CO}_{2}, \mathrm{O}_{2}, \mathrm{~N}_{2}\right)$ on inactivation of microorganisms. Giulitti 
et al. (2011) reported that non-acidic gas, such as $\mathrm{N}_{2} \mathrm{O}$, contributes to the destruction of membrane permeabilization and inactivates the cell. However, the inactivation rate was still low compared to $\mathrm{CO}_{2}$, because $\mathrm{CO}_{2}$ led to reduced intracellular $\mathrm{pH}$, and thus, more inactivation of cell. Vo et al. (2013) found that $\mathrm{CO}_{2}$ was more efficient for inactivation of E. coli at low pressure $(0.9 \mathrm{MPa})$ than $\mathrm{N}_{2} \mathrm{O}$ and $\mathrm{N}_{2}$; the $\log$ reduction was $5 \operatorname{logs}$ for $\mathrm{CO}_{2}$ compared to 3.3 and $2.4 \operatorname{logs}$ for $\mathrm{N}_{2} \mathrm{O}$ and $\mathrm{N}_{2}$, respectively. This may be due to acidification of the solution by $\mathrm{CO}_{2}$ while $\mathrm{N}_{2} \mathrm{O}$ leads to neutralization. They concluded that $\mathrm{CO}_{2}$ has the disinfection potential without undesirable by-products. Jimenez et al. (2008) and Kim et al. (2009) reported that the microorganisms can be inactivated under the moderate pressure and low temperature due to physical and chemical action on the cell.

In $\mathrm{SC}-\mathrm{CO}_{2}$, three principles are combined, $\mathrm{CO}_{2}$, temperature and pressure. $\mathrm{CO}_{2}$ is in a fluid state at or above critical temperature $\left(31.1^{\circ} \mathrm{C}\right)$ and critical pressure $(7.39 \mathrm{MPa})$. Therefore, the fluid $\mathrm{CO}_{2}$ is reasonably easy to tackle under supercritical conditions (Enomoto et al. 1997; Spilimbergo et al. 2002). The efficiency of $\mathrm{SC}-\mathrm{CO}_{2}$ on inactivation of microorganisms has been investigated since the 1980s (Calvo and Torres 2010). Several authors have reported that $\mathrm{SC}-\mathrm{CO}_{2}$ has the capability for the inactivation of several bacterial species such as $B$. subtitles spores (Spilimbergo and Bertucco 2003), B. pumilus spores (Zhang et al. 2006b), P. fluorescens (Werner and Hotchkiss 2006), S. typhimurium (Kim et al. 2007b), S. aureus and E. coli (Jimenez et al. 2008) and S. enteric (Kim et al. 2009).

The inactivation of pathogenic bacteria in clinical wastes by $\mathrm{SC}-\mathrm{CO}_{2}$ has also been investigated. Banana (2013) investigated the inactivation of Streptococcus group B, E. faecalis, S. aureus, E. coli, K. pneumonia, Salmonella spp., P. mirabilis and Bacillus sp. in human body fluids (blood, urine, pas) as well as tissue and swap using autoclave, microwave and $\mathrm{SC}-\mathrm{CO}_{2}$. It was observed that the technique achieved standard limits required for level I (6 log reduction) as recommended by STAATT (2005). However, the inactivated bacteria were regrown again in treated blood wastes. The amount of bacterial growth in blood wastes treated by $\mathrm{SC}-\mathrm{CO}_{2}$ was less than that treated by autoclave and microwave. These results were explained on the basis of moisture content. The moisture content of blood wastes treated by autoclave and microwave was on average 75 and $65 \%$, respectively, while it was less than $50 \%$ in blood wastes treated by $\mathrm{SC}-\mathrm{CO}_{2}$.

Hossain (2013) also investigated the inactivation of E. coli, P. aeruginosa, A. baumannii, $S$. aureus, B. subtilis, S. pyogenes, E. faecalis, $S$. marcescens and B. sphaericus in clinical solid waste by autoclave and $\mathrm{SC}-\mathrm{CO}_{2}$ technique. The results indicated that the bacterial strains were completely inactivated to meet standard limits (6 logs reduction) recommended by STAATT (2005). The regrowth was observed in samples treated by autoclave but not in those treated by SC- $\mathrm{CO}_{2}$. These differences between Banana (2013) and Hossain (2013) might be due to the nature of clinical wastes. Blood wastes are rich in nutrients and inactivation of pathogenic bacteria in this case is more complicated than in clinical solid wastes. In general, both studies concluded that the $\mathrm{SC}-\mathrm{CO}_{2}$ has efficiency for the inactivation of pathogenic bacteria in different types of clinical wastes.

In the concept of the global warming and zero discharge, $\mathrm{CO}_{2}$ used for $\mathrm{SC}-\mathrm{CO}_{2}$ can be reused again for several times. The maximum temperature used in $\mathrm{SC}-\mathrm{CO}_{2}$ is $80{ }^{\circ} \mathrm{C}$ compared to autoclave $\left(121^{\circ} \mathrm{C}\right)$, and incineration technique $\left(900-1200^{\circ} \mathrm{C}\right)$. Besides this, most of studies performed on $\mathrm{SC}-\mathrm{CO}_{2}$ have indicated that the inactivation rate of microorganism might be high even at low temperature and moderate pressure (Dillow et al. 1999; White et al. 2006; Zhang et al. 2006a). Thus, $\mathrm{SC}-\mathrm{CO}_{2}$ is recorded as an efficient technology for sterilizing food and inactivating microorganisms without distraction of the nutritional contents (Arreola et al. 
1991; Balaban et al. 2001; Gunes et al. 2005). This feature gives $\mathrm{SC}-\mathrm{CO}_{2}$ another advantage compared to incineration, microwave and autoclave for treating clinical wastes especially for recyclable and reusable wastes. Many solid wastes made up of heat liable biopolymers would not be destroyed as in the case of autoclave and microwave and can be reused or recycled. Reuse and recycling of solid waste material are, therefore, important to reduce volume of disposed wastes (Lee et al. 2002; Tudor 2007; Cheng et al. 2009). The comparison between different technologies for treatment of clinical wastes is illustrated in Table 3.

\section{Inactivation of Fungi Using $\mathrm{SC}-\mathrm{CO}_{2}$}

The supercritical carbon dioxide technique depends on the solubility and diffusion of pressure through the microorganism cell membrane (Zhang et al. 2006b). $\mathrm{CO}_{2}$ has a gas-like diffusivity and viscosity, liquid-like density and a zero surface tension. These properties facilitate the penetration of $\mathrm{CO}_{2}$ into complex structures of microorganisms and result in inactivation (Weibel and Ober 2002; Spilimbergo et al. 2009; Ortuno et al. 2012). The inactivation of fungal spores in clinical wastes have not been investigated yet. Therefore, in this section the possibility of $\mathrm{SC}-\mathrm{CO}_{2}$ to kill fungal spores in clinical wastes is evaluated based on studies conducted on the inactivation of fungi in food. Most of the studies have been carried out on A. niger spores because it is a common contaminant of foods. The studies revealed that SC$\mathrm{CO}_{2}$ showed an efficient inactivation for fungi. Haas et al. (1989) found that $P$. roqueforti spores in the growth medium were reduced by $5 \operatorname{logs}$ at $5.4 \mathrm{MPa}, 45^{\circ} \mathrm{C}, 120 \mathrm{~min}$ and by $6 \log$ at $5.4 \mathrm{MPa}, 45^{\circ} \mathrm{C}, 240 \mathrm{~min}$. Shimoda et al. (2002) reported that $A$. niger has inactivated by 3 $\log$ reductions at $19 \mathrm{MPa}, 46^{\circ} \mathrm{C}, 1.7 \mathrm{~min}, 5 \log$ at $19 \mathrm{MPa}, 48^{\circ} \mathrm{C}, 1.8 \mathrm{~min}$ and by $6.8 \operatorname{logs}$ at

Table 3 Comparison of different treatment technologies used for treating of clinical wastes

\begin{tabular}{|c|c|c|c|c|c|}
\hline & \multicolumn{4}{|c|}{ Treatment Technology } & \multirow[b]{2}{*}{$\mathrm{SC}-\mathrm{CO}_{2} *$} \\
\hline & Incineration & Autoclave & Microwave & $\begin{array}{l}\text { Chemical } \\
\text { Disinfection }\end{array}$ & \\
\hline Factor & Temperature & $\begin{array}{l}\text { Moist temperature } \\
\text { and pressure }\end{array}$ & Irradiation & Toxicity & $\begin{array}{l}\text { Pressure and } \\
\text { temperature }\end{array}$ \\
\hline Inactivation of pathogen & High & High & High & Moderate & High \\
\hline $\begin{array}{l}\text { Suitability } \\
\text { for clinical } \\
\text { waste }\end{array}$ & $\begin{array}{l}\text { Not for } \\
\text { Radioactive } \\
\text { wastes }\end{array}$ & $\begin{array}{l}\text { All except } \\
\text { Pathological } \\
\text { wastes }\end{array}$ & $\begin{array}{l}\text { All except } \\
\text { cytotoxic, } \\
\text { radioactive wastes }\end{array}$ & $\begin{array}{l}\text { Liquid } \\
\text { wastes }\end{array}$ & Yes \\
\hline $\begin{array}{l}\text { Zero discharge } \\
\text { of treated waste } \\
\quad(\text { Volume reduction } \%)\end{array}$ & $90-95$ & 0 & $60-90$ & $60-90$ & 0 \\
\hline Toxic by-product & High & Slight & Slight & High & No \\
\hline Environmental friendly & No & Yes & Yes & No & Yes \\
\hline Global warming & High & low & Moderate & No & No \\
\hline $\begin{array}{l}\text { Regrowth of inactivated } \\
\text { pathogen }\end{array}$ & No & Yes & Yes & Yes & Yes/No \\
\hline
\end{tabular}

Visvanathan (2006); Banana (2013); Hossain (2013); U.S. EPA (1990); Salkin (2003).

*more studies should be conducted for accurate evaluation of $\mathrm{SC}-\mathrm{CO}_{2}$, 
$19 \mathrm{MPa}, 50{ }^{\circ} \mathrm{C}, 1.5 \mathrm{~min}$ in physiological saline. Calvo et al. (2007) investigated the inactivation of $A$. niger and A. ochraceus spores in cocoa by $\mathrm{SC}-\mathrm{CO}_{2}$. They have recorded an inactivation of both fungal spores at $30 \mathrm{MPa}, 80{ }^{\circ} \mathrm{C}$ and after $30 \mathrm{~min}$ in $5 \%$ of water. Table 4 presents studies conducted on inactivation of fungi using $\mathrm{SC}-\mathrm{CO}_{2}$.

The efficiency of $\mathrm{SC}-\mathrm{CO}_{2}$ for inactivation of microorganisms depends on several factors such as temperature, pressure, time, moisture content, and chemical additives. The physical and chemical properties of the suspending medium play an effective role on the inactivation of microorganisms with increasing diffusivity of $\mathrm{CO}_{2}$ (White et al. 2006; Garcia-Gonzalez et al. 2007; Zhang et al. 2008; Spilimbergo et al. 2010). Among these factors, pressure and temperature have the most influence on inactivation rate (Garcia-Gonzalez et al. 2007; Valverde et al. 2010; Ferrentino et al. 2013).

The interaction between pressure and temperature on the inactivation process of microorganisms has been reported (Ferrentino et al. 2013). The increase of inactivation rate has been associated with pressure and temperature due to high solubility of $\mathrm{CO}_{2}$ in solution and increase of the diffusion rate into cell cytoplasm. Therefore, the increase of pressure and/or temperature reduced the duration of inactivation rate (Ballestra and Cuq 1998; Hong and Pyun 1999; DebsLouka et al. 1999; Garcia-Gonzalez et al. 2007). High pressure enhances the solubilization rate of $\mathrm{CO}_{2}$ in water, and thus, facilitates the acidification and membrane expansion, while high temperature stimulates $\mathrm{CO}_{2}$ diffusivity and increases the fluidity of cell membranes to make $\mathrm{CO}_{2}$ penetration easier (Lin et al. 1993; Spilimbergo 2002; Ferrentino et al. 2013).

Ballestra and Cuq (1998) studied the inactivation of $A$. niger spores in activity water $\left(a_{w}\right.$ 0.90 and 0.99 ) as well as at 50 and $60{ }^{\circ} \mathrm{C}$ at $5 \mathrm{MPa}$ pressure. They noted that A. niger inactivated $(>6 \operatorname{logs})$ at $5 \mathrm{MPa}$ and $50{ }^{\circ} \mathrm{C}$. Increasing of temperature up to $60{ }^{\circ} \mathrm{C}$ at same pressure decreased the inactivation rate by $\mathrm{CO}_{2}$. In contrast, decreasing of water activity from $a_{w} 0.99$ to 0.90 , increased the reduction of fungal spores. At 0.99 and $60{ }^{\circ} \mathrm{C}$ the inactivation

Table 4 Inactivation of fungal spores by Supercritical Carbon Dioxide $\left(\mathrm{SC}-\mathrm{CO}_{2}\right)$

\begin{tabular}{|c|c|c|c|c|}
\hline Fungal species & Sample & Treatment process & Log reduction & Reference \\
\hline A. niger & $\begin{array}{l}90 \% \text { water content } \\
2 \% \text { water content } \\
\text { With ethanol or acetic } \\
\text { acid addition }\end{array}$ & $20 \mathrm{MPa}, 35^{\circ} \mathrm{C}, 60 \mathrm{~min}$ & $\begin{array}{l}6 \operatorname{logs} \\
\text { ND } \\
6 \operatorname{logs}\end{array}$ & Kamihira et al. (1987) \\
\hline A. niger & Physiological saline & $\begin{array}{l}19 \mathrm{MPa}, 46^{\circ} \mathrm{C}, 1.7 \mathrm{~min} \\
19 \mathrm{MPa}, 48^{\circ} \mathrm{C}, 1.8 \mathrm{~min} \\
19 \mathrm{MPa}, 50^{\circ} \mathrm{C}, 1.5 \mathrm{~min}\end{array}$ & $\begin{array}{l}3 \log s \\
5 \log s \\
6.8 \log s\end{array}$ & Shimoda et al. (2002) \\
\hline A. niger & Cocoa with $5 \%$ water & $30 \mathrm{MPa}, 80^{\circ} \mathrm{C}, 30 \mathrm{~min}$ & $5.3 \log s$ & Calvo et al. (2007) \\
\hline$P$. roqueforti & Growth medium & $\begin{array}{l}5.4 \mathrm{MPa}, 45^{\circ} \mathrm{C}, 120 \mathrm{~min} \\
5.4 \mathrm{MPa}, 45^{\circ} \mathrm{C}, 240 \mathrm{~min}\end{array}$ & $\begin{array}{l}5 \log s \\
6 \log s\end{array}$ & Haas et al. (1989) \\
\hline $\begin{array}{l}\text { Byssochlamys } \\
\quad \text { fulva }\end{array}$ & Ringer solution & $\begin{array}{l}5.0 \mathrm{MPa}, 80^{\circ} \mathrm{C}, 85.5 \mathrm{~min} \\
5.0 \mathrm{MPa}, 85^{\circ} \mathrm{C}, 14.1 \mathrm{~min}\end{array}$ & $1 \log$ & Ballestra and Cuq (1998) \\
\hline A. ochraceus & Cocoa with $5 \%$ water & $30 \mathrm{MPa}, 80^{\circ} \mathrm{C}, 30 \mathrm{~min}$ & $3 \operatorname{logs}$ & Calvo et al. (2007) \\
\hline A. brassicicola & $\begin{array}{l}\text { In presence } 16 \% \text { Ethanol } \\
\text { Control }\end{array}$ & $15 \mathrm{MPa}, 38^{\circ} \mathrm{C}, 45 \mathrm{~min}$ & $\begin{array}{l}7 \operatorname{logs} \\
2 \operatorname{logs}\end{array}$ & Park et al. (2012) \\
\hline P. oxalicum & $\begin{array}{l}\text { With ethanol } \\
\text { Control }\end{array}$ & $\begin{array}{l}10 \mathrm{MPa}, 40^{\circ} \mathrm{C}, 45 \mathrm{~min} \\
20 \mathrm{MPa}, 45^{\circ} \mathrm{C}, 25 \mathrm{~min}\end{array}$ & Completely inactivation & Park and Kim (2013) \\
\hline A. ochraceus & Water & $\begin{array}{l}7 \mathrm{MPa}, 50{ }^{\circ} \mathrm{C}, 5.04 \mathrm{~min} \\
5.4 \mathrm{MPa}, 30^{\circ} \mathrm{C}, 7.07 \mathrm{~min}\end{array}$ & Completely inactivation & Neagu et al. (2014) \\
\hline
\end{tabular}


rate of fungal spores in the presence or absence of pressure was similar. On the basis of this study, it is concluded that the temperature has more influence on the inactivation rate at low pressure and water activity. In other words, the pressure showed a little effect at high temperature and water activity.

Neagu et al. (2014) investigated a mathematical model to study parameters of $\mathrm{SC}-\mathrm{CO}_{2}$ (pressure, temperature and time) for the inactivation of $A$. ocharaceusspores suspension. They found the optimal inactivation in the range 5.4 to $7.0 \mathrm{MPa}$ and 30 to $50{ }^{\circ} \mathrm{C}$. The decimal reduction time ranged from $47.07 \mathrm{~min}$ at $5.4 \mathrm{MPa}$ and $30^{\circ} \mathrm{C}$ to $5.04 \mathrm{~min}$ at $7.0 \mathrm{MPa}$ and $50{ }^{\circ} \mathrm{C}$.

The effect of moisture on the inactivation rate of microorganisms was also studied. These studies indicated that the inactivation process was reduced or even impaired in low water content environments (Haas et al. 1989; Kumagai et al. 1997; Dillow et al. 1999). Kamihira et al. (1987) investigated the inactivation of $A$. niger spores at $90 \%$ and $2 \%$ water content at $20 \mathrm{MPa}, 35{ }^{\circ} \mathrm{C}$ for $60 \mathrm{~min}$. The study found that the dry spores have remained unsterilized, while wet spores were reduced by 6 log cycles. Furukawa et al. (2009) demonstrated that Geobacillus stearothermophilus spores exhibited more resistance on inactivation process in the low water content. Conversely, Valverde et al. (2010) indicated that the inactivation of microorganisms by $\mathrm{SC}-\mathrm{CO}_{2}$ in the absence of water is faster than in the presence of water. It was observed that in solid materials, the contact between $\mathrm{CO}_{2}$ and the sample was direct, thus, the treatment period becomes shortened, as $\mathrm{CO}_{2}$ does not need to saturate the medium. In liquid substrates, the time required for $\mathrm{CO}_{2}$ to contact with target microorganism depends on the specific resistance. Indeed, many investigators demonstrated that the presence of moisture during $\mathrm{SC}-\mathrm{CO}_{2}$ induces the inactivation rate of microorganisms due to external $\mathrm{pH}$ reduction and promotion of membrane cell swelling, which increases the permeability of cell membrane and, thus, diffusion of $\mathrm{CO}_{2}$ is easier (Daniels et al. 1985; Lin et al. 1994; Werner and Hotchkiss 2006). The penetration of $\mathrm{CO}_{2}$ through cell membrane leads to alter the membrane functioning and cause intracellular disorders (García-Gonzalez et al. 2007). However, high water content might affect negatively on inactivation rate as mentioned by Ballestra and Cuq (1998). According to Haas et al. (1989) and Calvo et al. (2007), SC-CO $\mathrm{CO}_{2}$ is more effective in the presence of water. Calvo and Torres (2010) observed that the inactivation of bacteria in paprika progressively augmented as the water content increased to $35 \%$. In conclusion, the role of water content in $\mathrm{SC}-\mathrm{CO}_{2}$ inactivation of microorganisms is to increase the solubilisation of $\mathrm{CO}_{2}$, the acidification of the medium which leads to the increase of the diffusion and penetration of $\mathrm{CO}_{2}$ more easily across cell membrane into the intracellular, and the inhibition of microbial growth (Hong and Pyun 2001; Spilimbergo et al. 2002).

The constituents of the suspending media influence the inactivation rate of fungi. The nature of the matrix and the presence of compounds, such as carbohydrates and fats, play an important role in protecting microorganisms from high pressure $\mathrm{CO}_{2}$ (Ferrentino et al. 2013). Lin et al. (1994) indicated that the presence of fat in suspending media might lead to reduce inactivation rate, due to decrease in $\mathrm{CO}_{2}$ penetration into cells by changing the structure of cell walls and membranes. Erkmen (2000) noted that the inactivation of Brochothrix thermosphacta by $\mathrm{SC}-\mathrm{CO}_{2}$ in minced meat has achieved $1 \mathrm{log}(\mathrm{CFU} / \mathrm{g})$ reduction after $150 \mathrm{~min}$ at $6.1 \mathrm{MPa}$ and $45{ }^{\circ} \mathrm{C}$. Sirisee et al. (1998) studied the tolerance of E. coli and $S$. aureus inoculated in ground beef using $\mathrm{SC}-\mathrm{CO}_{2}$ treatment at $42.5^{\circ} \mathrm{C}$ and $31.03 \mathrm{MPa}$. The study found that these bacteria were reduced only by $1 \log$ after $178 \mathrm{~min}$.

The polarity of SC- $\mathrm{CO}_{2}$ increased significantly by adding the polar co-solvent to $\mathrm{CO}_{2}$ (Christensen and Kaufmann 1965). Kamihira et al. (1987) revealed that the dry spores of A. niger were reduced by $6 \operatorname{logs}$ when ethanol or acetic acid has been added to $\mathrm{SC}-\mathrm{CO}_{2}$ at 
$20 \mathrm{MPa}, 35^{\circ} \mathrm{C}$ for $60 \mathrm{~min}$, while the $\mathrm{SC}-\mathrm{CO}_{2}$ alone does not effect on the spores. Park et al. (2012) indicated that $A$. brassicicola spores were completely inactivated after $45 \mathrm{~min}$ at $15 \mathrm{MPa}$ and $38{ }^{\circ} \mathrm{C}$ when $16 \%$ ethanol was added to the solution compared to 2 log reduction in the control. Park and Kim (2013) investigated the inactivation of P. oxalicum spores suspension by $\mathrm{SC}-\mathrm{CO}_{2}$. They have recorded complete inactivation of $P$. oxalicum at $10 \mathrm{MPa}$ and $40{ }^{\circ} \mathrm{C}$ for $45 \mathrm{~min}$ by adding ethanol while the total inactivation was observed at $20 \mathrm{MPa}$, $45^{\circ} \mathrm{C}$ for $25 \mathrm{~min}$ without ethanol.

The optimal condition for inactivation of bacteria might not be appropriate for fungi. Hossain (2013) used glycerol as surfactant for the homogeneous distribution of bacteria in clinical solid wastes for inactivation by $\mathrm{SC}-\mathrm{CO}_{2}$. However, it has been reported since 1940 that the glycerol react with $\mathrm{CO}_{2}$ to produce succinic acid (Carson and Ruben 1940). Wu et al. (2011) indicated that this acid has inhibited growth and conidia germination of $F$. oxysporum. Thus, inactivation of fungi using $\mathrm{SC}-\mathrm{CO}_{2}$ in the presence of glycerol might be due to succinic acid and not to the action of SC- $\mathrm{CO}_{2}$. Moreover, STAATT (2005) recommended that the accurate evaluation of alternative technologies for inactivation of biological indicators in clinical wastes should be conducted without any chemical inactivation agent.

\section{Mechanism of Microbial Inactivation Using $\mathrm{SC}-\mathrm{CO}_{2}$}

Several hypotheses have explained the inactivation mechanism for microorganisms using SC$\mathrm{CO}_{2}$. The main mechanism of SC- $\mathrm{CO}_{2}$ is due to the effect of three parameters, which include pressure, temperature and time. Vo et al. (2013) noted that E. coli treated by $\mathrm{SC}_{-} \mathrm{CO}_{2}$ at 0.7 MPa for 25 min were totally lysed. Scanning Electron Microscope (SEM) examinations pointed out that the cell membranes of $E$. coli were completely damaged. The results of the absorbance analysis confirmed that bacterial nucleic acids and proteins could be easily extracted from $E$. coli cells. The authors indicated that the reduction in $\mathrm{pH}$ during the treatment by $\mathrm{CO}_{2}$ was likely the mechanism through which $\mathrm{CO}_{2}$ attenuated $E$. coli cells. Hossain (2013) reported that the $\mathrm{SC}-\mathrm{CO}_{2}$ has broken the cell wall and cell membrane of bacteria as determined by SEM. Thus, the bacterial cell was completely inactivated. The study reported that the one-dimensional SDS-PAGE analysis revealed absence of banding patterns of inactivated bacteria by SC-CO 2 versus the control (untreated). However, Lin et al. (1992 and 1993) have previously indicated that when $\mathrm{CO}_{2}$ concentrations reach critical level within cytoplasm, the cell loses the balance of biological systems and this leads to prompt inactivation even if the cell wall is not ruptured. SEM observations of Isenschmid et al. (1995), Ballestra et al. (1996) and White et al. (2006) indicated that microorganisms are not disrupted under relatively mild $\mathrm{CO}_{2}$ pressures.

White et al. (2006) recognized that the inactivation of bacterial cell was due to the effect of $\mathrm{SC}-\mathrm{CO}_{2}$ on intracellular contents rather than on cell wall. Transmission Electron Microscope (TEM) analysis conducted in their study indicated that the lipid bilayers of inactivated cells appeared to be 'roughened' compared to the control. The internal structure of the inactivated cells has appeared less distinct in the inactivated cells compared to untreated cells. Besides, both untreated and inactivated cells displayed similar banding patterns of protein in onedimensional SDS-Page analysis. Hong and Pyun (1999) suggested that $\mathrm{SC}-\mathrm{CO}_{2}$ treatment of bacterial cells has led to increase periplasmic space and fractures in cell membranes.

On the other hand, several authors observed the surface and internal structure changes induced by high-pressure $\mathrm{CO}_{2}$ treatment, such as burst cells, wrinkles and holes on the cell 
surface (Kamihira et al. 1987; Nakamura et al. 1994; Ballestra et al. 1996; Shimoda et al. 1998; Dillow et al. 1999). Kim et al. (2007a, 2007b) have proposed the inactivation of bacterial cells in three phases. In the first phase, which is called the lag phase, the efflux pump in the cell membrane is damaged, which leads to accumulation of toxic external substances inside the cells. The disruption of cell membrane integrity takes place throughout the exponential phase. In the stationary phases, DNA of bacterial cell is extracted outside the cell due to the damage of cell membrane. In order to confirm this mechanism, Kim et al. (2009) analysed the physiological status of $\mathrm{SC}-\mathrm{CO}_{2}$ treated $\mathrm{S}$. enterica serotype Typhimurium by using flow cytometry. The authors used ethidium bromide (EB) and propium iodide (PI) to evaluate the permeability of cell membrane and efflux pump system of bacteria. In untreated cells, EB was transported into the cytoplasm that can be pumped out of the cell via a non-specific proton antiport transport system (Jernaes and Steen 1994). In contrast, EB has stained the bacterial genomic (DNA) as a result of damage of membrane cell and the efflux pump. PI stain has the ability to enter into cell cytoplasm if the cells are dead (Ericsson et al. 2000; Humphreys et al. 1994). The results of systemic analyses conducted by Kim et al. (2009) revealed that the efflux pump was damaged after the treatment process by $\mathrm{SC}-\mathrm{CO}_{2}$ at mild conditions, while the membrane integrity was disrupted at temperatures greater than $50^{\circ} \mathrm{C}$ and $10 \mathrm{MPa}$.

Kim et al. (2009) used GC-MS analysis for fatty acids with principal component analysis (PCA) and two-dimensional electrophoresis (2-DE) for protein profiling of $S$. enterica serotype Typhimurium to investigate the mechanism of $\mathrm{SC}-\mathrm{CO}_{2}$. It was concluded that $\mathrm{SC}-\mathrm{CO}_{2}$ caused significant alterations to the profiles of fatty acids and proteins of the cells. GC-MS analysis recorded that the total fatty acid quantity of treated cells decreased significantly compared to control. The analysis of bacterial proteins by two-dimensional electrophoresis (2-DE) showed that the treatment process by using $\mathrm{SC}-\mathrm{CO}_{2}$ changed the cellular proteins.

The physiochemical inactivation of microorganism was a result of lowering of the intercellular pH. Giulitti et al. (2011) reported that the decreases of intracellular $\mathrm{pH}$ (pHi) during the treatment by $\mathrm{SC}-\mathrm{CO}_{2}$ were one of the factors which cause inactivation of microorganism because $\mathrm{pH}$ plays an important role in enzyme activity, gene transcription, and protein synthesis. They elucidated the mechanisms of dense gas inactivation of $S$. cerevisiae by measuring $\mathrm{pHi}$ under high pressure that was due to damage of permeability of cell membrane by $\mathrm{CO}_{2}$, while pHi decreased rapidly and led to more deactivations.

Few studies reported the effect of $\mathrm{SC}-\mathrm{CO}_{2}$ on inactivation of spores. Bacterial and fungal spores have a more complicated structure than the vegetative cells, and for this reason these spores are more resistant to $\mathrm{SC}-\mathrm{CO}_{2}$ treatment than vegetative cells. The studies indicated that temperature plays an important role in the inactivation process of spores. Bae et al. (2009) reported that increase of temperature leads to increase of log reduction of bacterial endospore more than that by increasing pressure. Calvo and Torres (2010) also concluded that the pressure was not the key factor for the antimicrobial effect of spores. As a result of complicated structure of dormant spores, the reactivation of these spores is necessary. The activated spores are more sensitive to treatment by $\mathrm{SC}-\mathrm{CO}_{2}$ than inactivated ones. Temperature can induce the reactivation of bacteria spores due to the reactivation of enzymes and release substrates required for germination (Keynan et al. 1964). Therefore, the increase of inactivation rate of spores during the treatment using $\mathrm{SC}-\mathrm{CO}_{2}$ might be due to the thermal revival of dormant spores (Calvo and Torres 2010). Watanabe et al. (2003a) and Furukawa et al. (2004) demonstrated that $\mathrm{CO}_{2}$ alone can promote the activation and germination of spores. However, this process requires high pressures ranging between 50 and $300 \mathrm{MPa}$, and needs to be combined with some heat (Norton and Sun 2008). These studies suggest that the $\mathrm{CO}_{2}$ treatment is 
substantially more effective than hydrostatic processes at much lower pressures (Watanabe et al. 2003b). Therefore, the inactivation of fungal spores by $\mathrm{SC}-\mathrm{CO}_{2}$ was due to the change of thermodynamic state of the $\mathrm{CO}_{2}$. It can be noted that the role of temperature used during $\mathrm{SC}$ $\mathrm{CO}_{2}$ treatment seems to be inducible for reactivation of spores, and then, increase the $\mathrm{CO}_{2}$ sporicidal effect (McDonnell 2007; Calvo and Torres 2010). In conclusion, the inactivation process of spores by $\mathrm{SC}-\mathrm{CO}_{2}$ was due to the thermodynamic state of $\mathrm{CO}_{2}$ but not due to hydrostatic action of pressure. SC- $\mathrm{CO}_{2}$ enhances mass-transfer properties of $\mathrm{CO}_{2}$ in a supercritical state, and thus, removes vital constituents from the cell membrane of spores (GarciaGonzalez et al. 2007).

The proposed mechanisms of bacterial inactivation by $\mathrm{SC}-\mathrm{CO}_{2}$ are presented in Fig. 3. This mechanism might be non-applicable for fungal cells due to difference between cell wall structure and cell cytoplasm between bacterial cell (prokaryotic) and fungal cell (eukaryotic). The cell wall structure affects the inactivation of microorganisms by SC$\mathrm{CO}_{2}$; for instance, Gram-negative bacteria were more sensitive to inactivation treatments than Gram-positive bacteria (Banana 2013). In fungi, only Park and Kim (2013) have investigated the effect of $\mathrm{SC}-\mathrm{CO}_{2}$ on cell wall and cell membrane. They have studied the effect of $\mathrm{SC}-\mathrm{CO}_{2}$ on membrane integrity and surface morphological changes of P. oxalicum (mycelia and spores) by Confocal Laser Scanning Microscopy (CLSM) and SEM. The fungal mycelia and spores stained by SYTO9 (green fluorescent) and PI (red fluorescent, selective stain for DNA and RNA) before and after the treatment processes at $20 \mathrm{MPa}$ and $45^{\circ} \mathrm{C}$ for $25 \mathrm{~min}$. They found that the untreated spores and mycelia stained more strongly with SYTO9 than with PI, whereas treated mycelia and spores have stained with a similar strength by SYTO9 and PI. These observations have indicated that the cell membrane has been disrupted. The monograph of SEM noted that the treated spores wrinkled compared to untreated ones. They have concluded that the $\mathrm{SC}-\mathrm{CO}_{2}$ can easily destruct the fungal spore surface and membrane.

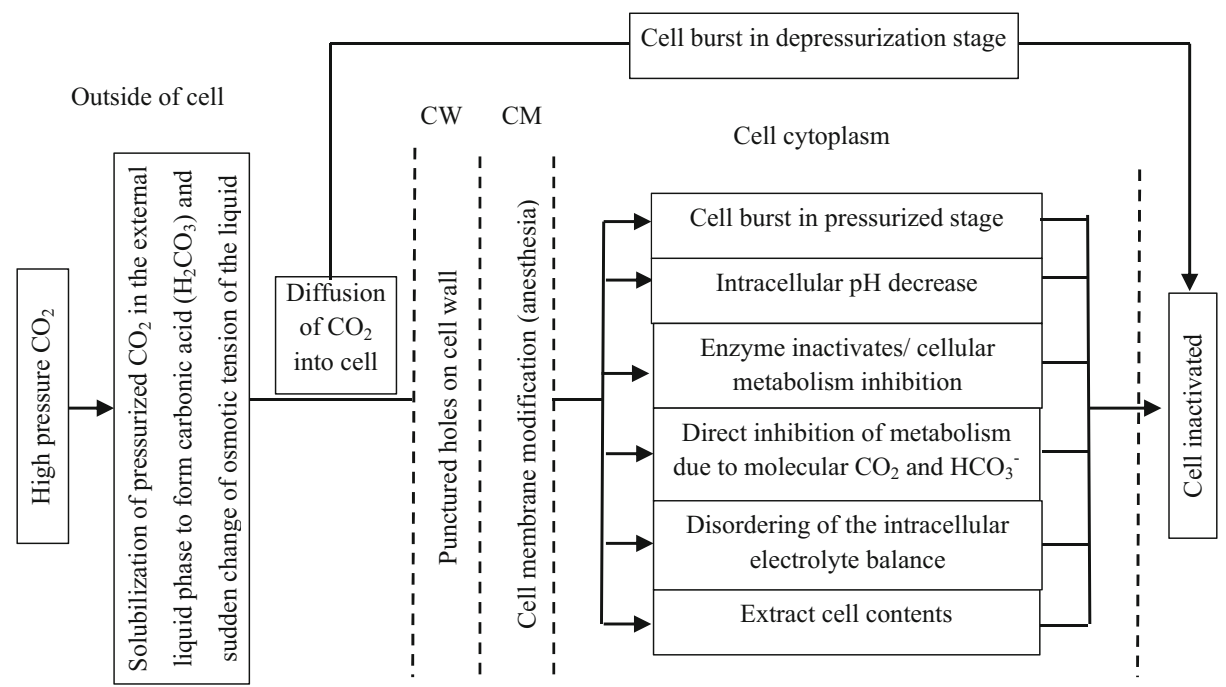

Fig. 3 Mechanism of inactivation process of vegetative bacterial cell by $\mathrm{SC}-\mathrm{CO}_{2}$; $\mathrm{CW}$ (cell wall), $\mathrm{CM}$ (cell membrane). The scheme of mechanism was proposed as reviewed by, Isenschmid et al. (1995), Ballestra et al. (1996), Zhang et al. (2006c), Garcia-Gonzalez et al. (2007) 


\section{Conclusions}

The clinical wastes contain several species of fungi that might represent a health risk for humans and the environment. Therefore, the clinical wastes should be treated before the disposal to the environment. $\mathrm{SC}-\mathrm{CO}_{2}$ is one of the sterilization technologies that depends on pressure and low temperature. The efficiency of $\mathrm{SC}-\mathrm{CO}_{2}$ for inactivation of microorganisms in food has been reported in the literature. In clinical wastes, the $\mathrm{SC}-\mathrm{CO}_{2}$ exhibited efficiency in inactivation of pathogenic bacteria. However, no investigation has been conducted on fungi. The studies conducted on fungi in different suspension media indicate that $\mathrm{SC}-\mathrm{CO}_{2}$ has a potential for inactivation of fungi. Therefore, it can be used as an alternative technology for treatment of clinical wastes.

Acknowledgments The authors gratefully acknowledge the Ministry of Science Technology and Innovation (MOSTI) for the research project financial support under FRGS Grant No. 203/PTEKIND/6711438) and APEX Grant 1002/PJJIUH/910324).

\section{References}

Abd El-Salam MM (2010) Hospital waste management in El-beheira government, Egypt. J Environ Manag 91: 618-629

Agalloco JP, Akers JE, Madsen RE (1998) Moist heat sterilization-myths and realities. PDA J Pharm Sci Technol $5(23): 46-50$

Alagoz AZ, Kocasoy G (2008) Determination of the best appropriate management methods for the healthcare waste in Istanbul. Waste Manag 28:1227-1235

Al-Ghamdi AY (2011) Review on hospital wastes and its possible treatments. Egy Acad J Biol Sci 3(1):55-62

Al-Gheethi AAS, NorliI I (2014) Biodegradation of pharmaceutical wastes in treated sewage effluents by Bacillus subtilis 1556WTNC. Environ Proc 1:459-489

Al-Gheethi AAS, Norli I, Lalung J, Azieda T, Efaq AN, Ab. Kadir MO (2013) Susceptibility for antibiotics among faecal indicators and pathogenic bacteria in sewage treated effluents. Water Practice Technol $8(1): 1-6$

Al-Gheethi AAS, Norli I, Lalung J, Megat-Azlan A, Nur-Farehah ZA, Ab. Kadir MO (2014) Biosorption of heavy metals and cephalexin from secondary effluents by tolerant bacteria. Clean Technol Environ Policy 16:137-148. doi:10.1007/s10098-013-0611-9

Al-Gheethi AAS, Aisyah M, Bala JD, Efaq AN, NorliI (2015) Prevalence of antimicrobial resistance among pathogenic bacteria from non-clinical environment. 4th International Conference on Environmental Research and Technology (ICERT 2015) on 27-29 May 2015 at Parkroyal Resort, Penang, Malaysia.

Al-Khatib IA, Sato C (2009) Solid health care waste management status at health care centers in the west bank. Palestinian territory. Waste Manag 29:2398-2403

Ambali A, Bakar AN, Merican FM (2013) Environmental policy in Malaysia: biomedical waste, strategies and issues. J Admin Sci 10:1

Aneja KR (2001) Experiments in Microbiology, Plant Pathology and Biotechnology. Section 9 control of Microorganism, 4th edition. New age international publishing.P.131

Anitha J, Jayraa IA (2012) Isolation and identification of bacteria from biomedical waste (BMW). Int J Pharm Sci 4(5):286-288

Araujo R, Gonçalves Rodrigues A, Pina-Vaz C (2006) Susceptibility pattern among pathogenic species of aspergillus to physical and chemical treatments. Med Mycol 44(5):439-443

Arreola AG, Balaban MO, Marshall MR, Peplow AJ, Wei CI, Cornell JA (1991) Supercritical carbon dioxide effects on some quality attributes of single strength orange juice. J Food Sci 56:1030-1033

Bae YY, Lee HJ, Kim SA, Rhee MS (2009) Inactivation of Alicyclobacillus acidoterrestris spores in apple juice by supercritical carbon dioxide. Int J Food Microbiol 136:95-100

Balaban MO, Kincal D, Hill S, Marshall MR, Wildasin R (2001) The synergistic use of carbon dioxide and pressure in nonthermal processing of juices, IFT annual meeting book of abstracts; 2001 june 23-27; New Orleans, La. Inst. of Food Technologists, Chicago 
Ballestra P, Cuq JL (1998) Influence of pressurized carbon dioxide on the thermal inactivation of bacterial and fungal spores. LWT Food Sci Technol 31:84-88

Ballestra P, Abreudasilva A, Cuq JL (1996) Inactivation of Escherichia coli by carbon dioxide under pressure. J Food Sci 61:829-831

Banana AAS (2013) Inactivation of pathogenic bacteria in human body fluids by steam autoclave, microwave and supercritical carbon dioxide. Ph.D. Thesis, Environmental Technology Division, School of Industrial Technology, UniversitiSains Malaysia (USM), Penang, Malaysia

Banana AAS, NikNorulaini NA, Baharom J, Zuraida MYL, Rafatullah M, AbKadir MO (2013) Inactivation of pathogenic micro-organisms in hospital waste using a microwave. J Mat Cycles Waste Manag 15(3):393403

Barcus AL, Burdette SD, Herchline TE (2005) Intestinal invasion and disseminated disease associated with Penicillium chrysogenum. Ann Clin Microbiol Antimicrob 4(1):21

Beck-Sague CM, Jarvis WR (1993) The national nosocomial infections surveillance system. Secular trends in the epidemiology of nosocomial fungal infections in the united states, 1980-1990. J Infect Dis 167:1247-1251

Bendjoudi Z, Taleb F, Abdelmalek F, Addou A (2009) Healthcare waste management in Algeria and mostaganem department. Waste Manag 29:1383-1387

Bi X, Wu J, Zhang Y, Xu Z, Liao X (2011) High pressure carbon dioxide treatment for fresh-cut carrot slices. Innov Food Sci Emerging Technol 12:298-304

Blenkharn JI (2005) Safe disposal and effective destruction of clinical wastes. J Hosp Infec 60:295-297

Bohm R (2004) Hygienic safety in organic waste management. In: Lens P, Hamerels B, Hoitink H, Bidlingmaier W (eds) Resource, recovery and reuse in organic solid waste management. IWA Publishing, London

Bond WW (1993) Biological indicators for a liquid chemical sterilizer. Infec Con Hosp Epidemiol 14:565

Brog MA (2007) Clinical wastes disposal-getting the facts right. J Hosp Infec 65(2):178-180

Bumann D, Hueck C, Aebischer T, Meyer TF (2000) Recombinant live Salmonella spp. for human vaccination against heterologous pathogens. FEMS Immunol Med Microbiol 27(4):357-364

Buzrul S (2009) Modeling and predicting inactivation of Escherichia coli under isobaric and dynamic high hydrostatic pressure. Innovative Food Sci Emerg Technol 10:391-395

Caldwell J (1965) Effects of high partial pressures of oxygen on fungi and bacteria. Nature 206:321-323

Calvo L, Torres E (2010) Microbial inactivation of paprika using high-pressure $\mathrm{CO}_{2}$. J Supercritical Fluids 52: 134-141

Calvo L, Muguerza B, Cienfuegos-Jovellanos E (2007) Microbial inactivation and butter extraction in a cocoa derivative using high pressure $\mathrm{CO}_{2}$. J Supercritical Fluids 42:80-87

Carson SF, Ruben S (1940) $\mathrm{CO}_{2}$ assimilation by propionic acid bacteria studied by the use of radioactive Carbon. Chem 26:422-426

CDC (2006) The national antimicrobial resistance monitoring system for enteric bacteria (NARMS): Human isolates final report. Atlanta, Georgia: U.S. Department of Health and Human Services, Centre for Disease Control (CDC)

CDC (2009) Guidelines for control of infections with carbapenemase-producing Enterobacteriaceae in acute care facilities. Centers for Disease Control and Prevention, CDC-MMWR 58:256-260

Cha CY, Carlisle CT (2001) Microwave process for volatile organic compound abatement. J Air Waste Manag Assoc 51:1628-1641

Cheng YW, Sung FC, Yang Y, Lo YH, Chung YT, Li KC (2009) Medical waste production at hospital and associated factors. Waste Mana 29(1):440-444

Christensen CM, Kaufmann HH (1965) Deterioration of stored grains by fungi. Ann Rev Phytopathol 3:69-84

Chuah A, Ghani L, Kamarulzaman Ab. (2009) Clinical waste management in Malaysia. In: IMPAK , Issue $3 / 2009$.

Chung CC, Huang TC, Li CY, Chen HH, (2013) Agriproducts Sterilization and Optimization by Using Supercritical Carbon Dioxide Fluid (SC-CO2). 4th International Conference on Food Engineering and Biotechnology Singapore, 1-8

Coker AO, Akanmu AM, Sridhar MKC, Aladenola IO (2000) Management of pollution from a hospital incinerator in Nigeria. Air Pollution VIII. WIT Press, Southampton, pp 253-260

Coker A, Sangodoyin A, Sridhar M, Booth C, Olomolaiye P, Hammond F (2009) Medical waste management in Ibadan, Nigeria: obstacles and prospects. Waste Manag 29:804-811

Crawford SE, Daum RS (2008) Pediatric respiratory medicine (2nd edition); chapter 35 -bacterial pneumonia, lung abscess and empyema. Mosby, Philadelphia, pp 501-553

Da Silva CE, Hoppe AE, Ravanello MM, Mello N (2005) Medical wastes management in the south of Brazil. Waste Manag 25:600-605

Daniels JA, Krishnamurthi R, Rizvi SS (1985) A review of effects of carbon dioxide on microbial growth and food quality. J Food Prot 48:532-537

Deacon J (2005) Fungal biology 4th edition. Blackwell Publishing Ltd., Malden. doi:10.1002/9781118685068 
Debs-Louka E, Louka N, Abraham G, Chabot V, Allaf K (1999) Effect of compressed carbon dioxide on cell viability. Appl Environ Microbiol 65:626-631

Department of Health (2013) Health technical memorandum 07-01: Safe management of healthcare waste. Department of Health, UK

Dillow AK, Dehghani F, Hrkach JS, Foster NR, Langer R (1999) Bacterial inactivation by using near- and supercritical carbon dioxide. Proc Natl Acad Sci U S A 96:10344

Dobrindt U, Hacker J (2008) Targeting virulence traits: potential strategies to combat extraintestinal pathogenic E. coli

DS (2013) Environmental statistics time series, Department of Statistics, Malaysia. ISSN 2289-2060

Duong TA (1996) Infection Due to penicillium marneffei, an emerging pathogen: review of 155 reported cases. Clinic Infect Dis 23:125-130

Eckmanns T, Oppert M, Martin M, Amorosa R, Zuschneid I (2008) An outbreak of hospital-acquired Pseudomonas aeruginosa infection caused by contaminated bottled water in intensive care units. Clinical Microbiology Infec 14:454 458

Efaq AN, Al-Gheethi AA (2015) Management of Clinical Solid Wastes Generated from Healthcare Facilities in Yemen. 3rd International Conference on Sustainable Solid Waste Management, 2-4 July 2015, Tinos Island, Greece

Efaq AN, Nagao H, NikNorulaini NA, Al-Gheethi AAS, Ab. Kadir MO (2015) Survival of opportunistic fungi in clinical wastes. 4th International Conference on Environmental Research and Technology (ICERT 2015) on 27-29 May 2015 at Parkroyal Resort, Penang, Malaysia

Enomoto A, Nakamura K, Hakoda M, Amaya N (1997) Lethal effect of high-pressure carbon dioxide on a bacterial spore. J Ferment Bioeng 83:305-307

U.S. EPA (1990) Summary of potential risks from hospital waste incineration: Pathogens in air emission and residues. EACO-R-0238

EPA (2009) Guidance for wastes and resources regulated under the Environment Protection (Industrial Waste Resource) Regulations 2009. Publication IWRG 612.1, Environmental Protection Agency, Victoria

Ericsson M, Hanstorp D, Hagberg P, Enger J, Nystrom T (2000) Sorting out bacterial viability with optical tweezers. J Bacteriol 182:5551-5555

Erkmen E (2000) Antimicrobial effects of pressurized carbon dioxide on Brochotrixthermosphacta in broth and foods. J Sci Food Agric 89:1365-1370

Facklam RR, Washington JA (1991) Streptococcus and related catalase-negative gram-positive cocci. In: Balows A, Hausler WJ Jr, Herrmann KL, Isenberg HD, Shadomy HJ (eds) Manual of clinical microbiology, 5 th edn. American Society for Microbiology, Washington, pp 238-257

Ferrentino G, Balzan S, Dorigato A, Pegoretti A, Spilimbergo S (2012) Effect of supercritical carbon dioxide pasteurization on natural microbiota, texture and microstructure of fresh cut coconut. J Food Sci 77:137-143

Ferrentino G, Balzan S, Spilimbergo S (2013) Optimization of supercritical carbon dioxide treatment for the inactivation of the natural microbial flora in cubed cooked ham. Int J Food Microbiol 161:189-196

Fijalkowski KL, Kacprzak MJ, Rorat A (2014) Occurrence changes of Escherichia coli (including O157:H7 serotype) in wastewater and sewage sludge by quantitation method of (EMA) real time-PCR. Desalin Water Treat 52:19-21

Fluit AC, Jones ME, Schmitz FJ, Acar J, Gupta R, Verhoef J (2000) Antimicrobial susceptibility and frequency of occurrence of clinical blood isolates in Europe from the sentry antimicrobial surveillance program, 1997 and 1998. Clinical Infection Dis 30:454-460

Freitas AR, Novais C, Correia R, Monteiro M, Coque TM, Peixe L (2011) Non-susceptibility to tigecycline in enterococci from hospitalised patients, food products and community sources. Int J Antimicrob Agents 38: $174-176$

Furukawa S, Watanabe T, Tai T, Hirata J, Narisawa N, Kawarai T, Ogihara H, Yamasaki M (2004) Effect of high pressure gaseous carbon dioxide on the germination of bacterial spores. Int J Food Microbiol 91:209-213

Furukawa S, Watanabe T, Koyama T, Hirata J, Narisawa N, Ogihara H, Yamasaki M (2009) Inactivation of food poisoning bacteria and Geobacillusstearother-mophilus spores by high pressure carbon dioxide treatment. Food Control 20:53-58

Garcia-Gonzalez L, Geeraerd AH, Spilimbergo S, Elst K, Van Ginneken L, Debevere J, Van Impe JF, Devlieghere F (2007) High pressure carbon dioxide inactivation of microorganisms in foods. The past, the present and the future. Int J Food Microbiol 117:1-28

Garrison MW, Neumiller JJ, Setter SM (2005) Tigecycline: an investigational glycylcycline antimicrobial with activity against resistant gram-positive organisms. Clin Ther 27(1):12-22

Giulitti S, Cinquemani C, Spilimbergo S (2011) High pressure gases: role of dynamic intracellular $\mathrm{pH}$ in pasteurization. Biotechnol Bioeng 108(5):1211-1214

Gunes G, Blum LK, Hotchkiss JH (2005) Inactivation of yeasts in grape juice using a continuous dense phase carbon dioxide processing system. J Sci Food Agri 85:2362-2368 
Haas GJ, Prescott HE, Dudley E, Dik R, Hintlian C, Keane L (1989) Inactivation of microorganisms by carbon dioxide under pressure. J Food Safety 9:253-265

Halbwachs H (1994) Solid waste disposal in district health facilities. World Health Forum 15:363-367

Hall SK (1989) Infectious waste management: a multifaced problem. J Poll Engin 21(8):74-78

Hayakawa K, Ueno Y, Kawamura S, Kato T, Hayashi R (1998) Microorganism inactivation using high-pressure generation in sealed vessels under sub-zero temperature. Appl Microbiol Biotechnol 50:415-418

Hite BH, Giddings NJ, Chas E, Weakley J (1914) The effect of pressure on certain microorganisms encountered in the preservation of fruits and vegetables. Departments of Chemistry and Plant Pathology, Technical Bulletin 146.Virginia University, USA.

Hogan LJ, Klein BS, Levitz SM (1996) Virulence factors of medically important fungi. Clinic Microbiol Rev 9(4):469-488

Hong SI, Pyun YR (1999) Inactivation kinetics of Lactobacillus plantarum by high pressure carbon dioxide. J Food Sci 64:728

Hong SI, Pyun YR (2001) Membrane damage and enzyme inactivation of Lactobacillus plantarumbyhigh pressure $\mathrm{CO}_{2}$ treatment. Int J Food Microbiol 63:19-28

Hossain S (2013) Supercritical carbon dioxide sterilization of clinical solid waste. Ph.D Thesis, Environmental Technology Division, School of Industrial Technology, University Science Malaysia. Penang, Malaysia.

Humphreys MJ, Allman R, Lloyd D (1994) Determination of the viability of Trichomonas vaginalis using flow cytometry. Cytometry 15:343-348

Hungaro HM, Pelia WEL, Silva NBM, Carvalho RV, Alvarenga VO, Sant-Ana AS (2014) Food microbiology, 1st edition, Elsevier publishing

Isenschmid A, Marison LW, von Stockar U (1995) The influence of pressure and temperature of compressed $\mathrm{CO}_{2}$ on the survival of yeast cells. J Biotechnol 39:229-237

Jang YC, Lee C, Yoon OS, Kim H (2006) Medical waste management in Korea. J Environ Manag 80:107-115 Jay JM (2000) Modern food microbiology, 6th edition. Aspen Publishers, Inc. Gaithersburg, Maryland

Jernaes MW, Steen HB (1994) Staining of Escherichia coli for flow cytometry: influx and efflux of ethidium bromide. Cytometry 17:302-309

Jimenez A, Zhang J, Matthews MA (2008) Evaluation of $\mathrm{CO}_{2}$-based cold sterilization of a model hydrogel. Biotechnol Bioeng 101:1344-1352

Johannessen LM (1997) Management of health care waste. In: Proceedings in Environment '97 Conference, 1618 February 1997, Cairo. Dokki-Giza, Egyptian Environmental Affairs Agency

Johnson DW, Murphy JF, Susfalk RB, Caldwell TG, Miller WW, Walker RF, Powers RF (2005) The effects of wildfire, salvage logging, and post-fire $\mathrm{N}$-fixation on the nutrient budgets of a Sierran forest. Forest Ecol Mana 220(1-3):155-165

Kamihira M, Taniguchi M, Kobayashi T (1987) Sterilization of microorganisms with supercritical and liquid carbon dioxide. Agricul Biol Chem 51:407-412

Keynan A, Evenchik Z, Halvorson HO, Hastings JW (1964) Activation of bacterial endospores. J Bacteriol 88(2):313-318

Kiil K, Binnewies TT, Willenbrock H, Hansen SK, Yang L, Jelsbak L, Ussery DW, Friis C (2008) Comparative genomics of Pseudomonas; in pseudomonas model organism, pathogen, cell factory by Bernd, H. A. and Rehm, WILEY-VCH Verlag GmbH and Co. KGA, Weinheim

Kim SR, Rhee MS, Kim BC, Kim KH (2007a) Modeling the inactivation of Escherichia coli O157:H7 and generic Escherichia coli by supercritical carbon dioxide. Int J Food Microbiol 118:52-61

Kim SR, Rhee MS, Kim BC, Lee H, Kim KH (2007b) Modeling of the inactivation of Salmonella typhimurium by supercritical carbon dioxide in physiological saline and phosphate-buffered saline. J Microbiol Methods 70:132-141

Kim SR, Kim HT, Park HJ, Kim S, Choi HJ, Hwang GS, Yi JH, Ryu do H, Kim KH (2009) Fatty acid profiling and proteomic analysis of Salmonella enterica serotype Typhimurium inactivated with supercritical carbon dioxide. Int J Food Microbiol 134(3):190-195

Kumagai H, Hata C, Nakamura K (1997) $\mathrm{CO}_{2}$ sorption by microbial cells and sterilization by high-pressure $\mathrm{CO}_{2}$. Biosci Biotechnol Biochem 61:931-935

Larson WP, Hartzell TB, Diehl HS (1918) The effect of high pressure on bacteria. J Infec Dis 22(3):271-279

Lee BK, Ellenbecker MJ, Moure-Eraso R (2002) Analyses of the recycling potential of medical plastic wastes. Waste Manag 22:461-470

Lee BK, Ellenbecker MJ, Moure-Eraso R (2004) Alternatives for treatment and disposal cost reduction of regulated medical waste. Waste Manag 24:143-151

Lin HM, Yang Z, Chen LF (1992) Inactivation of Saccharomyces cerevisiae by supercritical and subcritical carbon dioxide. Biotechnol Prog 8:458-461

Lin HM, Yang Z, Chen LF (1993) Inactivation of Leuconostocdextranicum with carbon dioxide under pressure. Chem Eng J 52:29-34 
Lin HM, Cao N, Chen LF (1994) Antimicrobial effect of pressurized carbon dioxide on Listeria monocytogenes. J Food Sci 59:657-659

Luksamijarulkul P, Parikumsil N, Poomsuwan V (2006) Nosocomial surgical site infection among photharam hospital patients with surgery: incidence, risk factors and development of risk screening form. J Med Assoc Thail 89:81-89

Macêdo DPC, Silva-Júnior HM, Souza-Motta CM, Milan EP, Neves RP (2009) Invasive aspergillosis associated with systemic lupus erythematosus and cardiac postoperative complication. Braz J Microbiol 40(1):180-183

Malinowska-Pańczyk E, Kołodziejska I, Dunajski E (2008) Effect of high pressure on selected bacteria at subzero temperature. Polish J Food Nutrition Sci 58(4):419-424

Marinkovic N, Pavic T, Vitale K, Holcer NJ, Dzakula A (2008) Management of hazardous medical waste in croatia. Waste Manag 28:1049-1056

McDonnell GE (2007) Antisepsis, Disinfection and Sterilization: Types, Action and Resistance, ASM Press, Washington, DC

Michelle A, Pat Cr, Paul J (2001) Incineration and human health state of knowledge of the impacts of waste incinerators on human health. Greenpeace Research Laboratories, University of Exeter, UK

Ministry of Environment and Forestry (2005) Medical Waste Control Regulation. Official Gazette No. 25883, Ankara, Turkey.

Ministry of Health (1998) Waste management guidelines for health care facilities - august 1998. Policy Directive, Australia

Nakamura K, Enomoto A, Fukushima H, Nagai K, Hakoda M (1994) Disruption of microbial-cells by the flash discharge of high-pressure carbondioxide. Biosci Biotechnol Biochem 58:1297

Neagu C, Borda D, Erkmen O (2014) Mathematical modelling of Aspergillus ochraceus inactivation with supercritical carbon dioxide - A kinetic study. Food Bioprod Proces 92(4):369-375

Neely AN, Orloff MM (2001) Survival of some medically important fungi on hospital fabrics and plastics. J Clinic Microbiol 39:3360-3361

Nemathaga F, Maringa S, Chimuka L (2008) Hospital solid waste management practices in Limpopo province, south africa: a case study of two hospitals. Waste Manag 28:1236-1245

Niwagaba CB (2009) Treatment technologies for human faeces and urine. Ph.D Thesis, Swedish University of Agricultural Sciences, Sweden

Norton T, Sun DW (2008) Recent advances in the use of high pressure as an effective processing technique in the food industry. Food Bioprocess Technol 1:2-34

Ortuno C, Martínez-Pastor MT, Mulet A, Benedito J (2012) Supercritical carbon dioxide inactivation of Escherichia coli and Saccharomyces cerevisiae in different growth stages. J Supercritical Fluids 63:8-15

Oshikata C, Tsurikisawa N, Saito A, Watanabe M, Kamata Y, Tanaka M, Tsuburai T, MitomiH TK, YasuedaH AK (2013) Fatal Pneumonia Caused by Penicillium digitatum. BMC Pulm Med 13(16)

Oyeleke SB, Istifanus N (2009) The microbiological effects of hospital wastes on the environment. Afr J Biotechnol 8(22):6253-6257

Pagani L, Migliavacca R, Pallecchi L, Matti C, Giacobone E, Amicosante C (2002) Emerging extended-spectrum beta-lactamase in Proteus mirabilis. J Clin Microbiol 40:1549-1552

Pagano L, Akova M, Dimopoulos G, Herbrecht R, Drgona L, Blijlevens N (2011) Risk assessment and prognostic factors for mould-related diseases in immunocompromised patients. J Antimicrob Chemother 66(Suppl 1):5-14

Park HS, Kim KH (2013) Enhancement of supercritical $\mathrm{CO}_{2}$ inactivation of spores of Penicillium oxalicum by ethanol cosolvent. J Microbiol Biotechnol 23(6):833-836

Park H, Lee H, Kim M, Lee J, Seong SY, Ko G (2009) Detection and hazard assessment of pathogenic microorganisms in medical waste. J Environ Sci Health Part A 44:995-1003

Park HS, Choi HJ, Kim KH (2012) Inactivation of Alternaria brassicicola spores by supercritical carbon dioxide with ethanol entrainer. J Microbiol Methods 88:185-187

Pathak AK (2012) An extramural aeromycological investigation of dental college hospital associated environment. Int J Environ Sci 2(4):1952-1961

Phillips G (1999) Microbiological aspects of clinical wastes. J Hosp Infec 41(1):1-6

Podschun R, Ullmann U (1998) Klebsiella spp. as nosocomial pathogens: epidemiology, taxonomy, typing methods, and pathogenicity factors. Clinic Microbiol Rev 11:589-603

Pruss A, Giroult E, Rushbrook P (1999) Safe Management of Wastes from Healthcare Activities. World Health Organization, Geneva. WHO Library Cataloguing-in-Publication Data ISBN 9241545259

Raghubeer EV, Matches JR (1990) Temperature range for growth of Escherichia coli serotype O157:H7 and selected coliforms in E. coli medium. J Clinic Microbiol 28(4):803-805

Ramirez-Rogrigues MM, Plaza ML, Ferrentino G, Balaban MO, Reyes-De Concuera JI, Marshall MR (2013) Effect of dense phase carbon dioxide processing on microbial stability phycochemical attributes of Hibiscus Sabdariffa beverage. J Food Proc Eng 36(1):125-133 
Razali SS, Ishak MB (2010) Clinical waste handling and obstacles in Malaysia. J Urban Environ Eng 4(2):47-54

Renois F, Jacques J, Guillard T, Moret H, Pluot M, Andreoletti L, De Champs C (2011) Preliminary investigation of a mice model of Klebsiella pneumoniae subsp. ozaenae induced pneumonia. Microb Infect 13:1045-1051

Robb SM (1966) Reactions of fungi to exposure to 10 atmospheres pressure of oxygen. J Gen Microbiol Mol 45: $17-29$

Ruoyan G, Lingzhong X, Huijuan L, Chengchao Z, Jiangjiang H, Yoshihisa S, Wei T, Chushi K (2010) Investigation of healthcare waste management in binzhou district China. Waste Manag 30:246-250

Russell AD (1999) Destruction of bacterial spores by thermal methods. In: Russell AD, Hugo WB, Ayliffe GAJ (eds) Principles and practice of disinfection, preservation and sterilization, 3rd edn. Blackwell Science, Oxford, pp 640-656

Ryan KJ (2004) Candida, Aspergillus and other opportunistic fungi. In: Ryan KJ, Ray CG (eds) Sherris medical microbiology, 4th edn. McGraw-Hill, USA, pp 659-668

Şahil D, Otag F (2013) Filamentous fungi isolated from clinical samples stored for a long time in the sand. Clinic Microbial 2(1):1-2

Saini S, Das KB, Kapil A, Nagargan S, Sarma RK (2004) The study of bacterial flora of different types in hospital waste: evaluation of waste treatment at aims hospital, New Delhi. The Southeast Asian J Trop Med public health 35(4):986-98

Salkin IF (2003) Conventional and alternative technologies for the treatment of infectious waste. J Material Cycles Waste Manag 5:9-12

Segal BH (2009) Aspergillosis. New England J Med 360(18):1870-1884

Sherman W (2007) Reducing medial waste. JAMA 23:2583-2584

Shimoda M, Yamamoto Y, Cocunubo-Castellanos J, Tonoike H, Kawano H, Ishikawa H, Osajima Y (1998) Antimicrobial effects of pressured carbon dioxide in a continuous flow system. J Food Sci 63:709

Shimoda M, Kago H, Kojima N, Miyake M, Osajima Y, Hayakawa I (2002) Accelerated death kinetics of Aspergillus niger spores under high-pressure carbonation. Appl Environ Microbiol 68(8):4162-4167

Shinee E, Gombojav E, Nishimura A, Hamajima N, Ito K (2008) Healthcare waste management in the capital city of Mongolia. Waste Manag 28:435-441

Sifuentes-Osornio J, Corzo-León DE, Ponce-de-León LA (2012) Epidemiology of invasive fungal infections in Latin America. Curr Fungal Infect Rep 6:23-34

Sirisee U, Hsieh F, Huff HE (1998) Microbial safety of supercritical carbondioxide processes. J Food Proc Preser 22:387-403

Smerage GH, Teixeira AA (1993) Dynamics of heat destruction of spores: a new view. J Ind Microbiol 12:211220

Spilimbergo S (2002) A study about the effect of dense $\mathrm{CO}_{2}$ on microorganisms, $\mathrm{PhD}$ thesis, University of Padova, Italy, 2002

Spilimbergo S, Bertucco A (2003) Non-thermal bacterial inactivation with dense $\mathrm{CO}_{2}$. Biotechnol Bioeng 84: $627-638$

Spilimbergo S, Elvassore N, Bertucco A (2002) Microbial inactivation by high-pressure. J Supercritical Fluids 22:55-63

Spilimbergo S, Mantoan D, Quaranta A, Della G (2009) Real-time monitoring of cell membrane modification during supercritical $\mathrm{CO}_{2}$ pasteurization, J Supercritical Fluids 48 (2009) 93-97

Spilimbergo S, Foladori P, Mantoan D, Ziglio G (2010) Assessment of high pressure $\mathrm{CO}_{2}$ inactivation and induced damage on $S$. cerevisiae by flow cytometry. Process Biochem 45:647-654

STAATT (2005) Technical assistance manual: state regulatory oversight of medical waste treatment technology. Report of the state and territorial association on alternative treatment technologies (SAATT)

Stocker TF, Dahe Q, Plattner GK (2013) Technical Summary, IPCC AR5 WG1 2013

Tamring S, Lane T, Mohd-Shah SH, Shanmuganathan S, Khaithir TMN, Shuid AN, Borhanuddin B, Mohamed IN (2014) Amphotericin b-deoxycholate is as effective and safe as the costly amphotericin b colloidal dispersion in the treatment of paediatric invasive fungal infections. J Pharm Nut Sci 4:228-237

Tang JW (2009) The effect of environmental parameters on the survival of airborne infectious agents. J R Soc Int 6(6):S737-S746

Tsakona M, Anagnostopoulou E, Gidarakos E (2007) Hospital waste management and toxicity evaluation: a case study. Waste Manag 27:912-920

Tudor TL (2007) Towards the development of a standardized measurement unit for healthcare waste generation. Res Conserv Recy 50(3):319-333

Valverde MT, Marín-Iniesta F, Calvo L (2010) Inactivation of Saccharomyces cerevisiae in conference pear with high pressure carbon dioxide and effects on pear quality. J Food Engin 98:421-428

van Burik JA, Magee PT (2001) Aspects of fungal pathogenesis in humans. Annu Rev Microbiol 55:743-72

Vanittanakom N, Cooper CR Jr, Fisher MC, Sirisanthana T (2006) Penicillium marneffei infection and recent advances in the epidemiology and molecular biology aspects. Clinic Microbiol Rev 19(1):95-110 
Vickery AM (1993) Strains of methicillin-resistant Staphylococcus aureus isolated in Australian hospitals from 1986 to 1990 . J Hosp Infec 24(2):139-151

Vieira CD, de Carvalho MAR, de Resende MA, de Menezes-Cussiol NA, Alvarez-Leite ME, dos Santos SG, de Oliveira MB, de Magalhaes TFF, Silva MX, Nicoli JR de MacedoFarias L (2010) Isolation of clinically relevant fungal species from solid waste and environment of dental health services. Lett Appl Microbiol 51: $370-376$

Visvanathan C (2006) Medical waste management issues in Asia. Asia 3rd Conference, 30 October - 1 November, 2006 Tokyo, Japan

Vo HT, Imai T, Teek J, Sekine M, Kanno A, Le AV, Higuchi T, Phummala K, Yamamoto K (2013) Comparison of disinfection effect of pressurized gases of $\mathrm{CO} 2, \mathrm{~N} 2 \mathrm{O}$, and $\mathrm{N} 2$ on Escherichia coli. Water Res 47:42864293

Watanabe K, Kakita Y, Kashige N, Miake F, Tsukiji T (2000) Effect of ionic strength on the inactivation of micro-organisms by microwave irradiation. Lett Appl Microbiol 31:52-56

Watanabe T, Furukawa S, Hirata J, Koyama T, Ogihar H, Yamasaki M (2003a) Inactivation of Geobacillusstearothermophilus spores by high pressure carbon dioxide treatment. Appl Environ Microbiol 69:7124-7129

Watanabe T, Furukawa S, Tai T, Hirata J, Narisawa H, Ogihara H, Yamasaki M (2003b) High pressure carbon dioxide decreases the heat tolerance of the bacterial spores. Food Sci Technol Res 9(4):342-344

Weibel GL, Ober CK (2002) An overview of supercritical $\mathrm{CO}_{2}$ applications in microelectronics processing. Microelect Eng 65:145-152

Werner BG, Hotchkiss JH (2006) Continuous flow non-thermal $\mathrm{CO}_{2}$ processing: The lethal effects of subcritical and supercritical $\mathrm{CO}_{2}$ on total microbial populations and bacterial spores in raw milk. J Dairy Sci 89:872881

White A, Burns D, Christensen TW (2006) Effective terminal sterilization using supercritical carbon dioxide. J Biotechnol 123(4):504-515

WHO (2000) Wastes from healthcare activities. Fact sheet No. 353, World Health Organisation, Geneva

WHO (2005) Management of solid healthcare waste at primary healthcare centres. A Decision Making Guide, Geneva

Wu HS, Liu YD, Zhao GM, Chen XO, Yang XN, Zhou XD (2011) Succinic acid inhibited growth and pathogenicity of in vitro soil-borne fungus Fusarium oxysporum f. sp. niveum. Acta Agriculturae Scandinavica, Section B Soil Plant Sci 61(5):404-409

Zhang J, Burrows S, Gleason C, Matthews MA, Drews MJ, LaBerge M, An YH (2006a) Sterilizing Bacillus Pumilus spores using supercritical carbon dioxide. J Microbiol Methods 66:479-485

Zhang J, Dalal N, Gleason C, Matthews MA, Waller LN, Fox KF, Fox A, Drews MJ, LaBerge M, An YH (2006b) The mechanisms of deactivation of Bacillus atrophaeus spores using supercritical carbon dioxide. J Supercritical Fluids 38:268-273

Zhang J, Davis TA, Matthews MA, Drews MJ, LaBerge M, An YA (2006c) Sterilization using high-pressure carbon dioxide. J Supercritical Fluids 38:354-372

Zhang QY, Qian JQ, Guo H, Yang SL (2008) Supercritical $\mathrm{CO}_{2}$ : A novel environmentally friendly mutagen. J Microbiol Methods 75:25-28 